\title{
A phage-compatible strategy to access macrocyclic peptides featuring asymmetric molecular scaffolds as cyclization units
}

\author{
Titia Rixt Oppewal ${ }^{1}$, Johan Hekelaar ${ }^{1}$ and Clemens Mayer ${ }^{1, *}$
}

\author{
Affiliations \\ ${ }^{1}$ Stratingh Institute, University of Groningen, Nijenborgh 4, 9747 AG Groningen, \\ Netherlands \\ *Correspondence to: c.mayer@rug.nl
}

\begin{abstract}
The cyclization of peptides appended onto proteins or whole bacteriophages is typically achieved via disulfide formation, the use of symmetric crosslinkers or the incorporation of noncanonical amino acids. Unfortunately, neither of these strategies is amenable toward generating libraries for the selection of macrocyclic peptides (MPs) akin to those found in nature, which often feature asymmetric molecular scaffolds as cyclization units that improve binding to their targets. To meet this challenge, we present an efficient two-step strategy to access MPs via the programmed modification of a unique cysteine residue and an $\mathrm{N}$-terminal amine. We demonstrate that this approach yields MPs featuring asymmetric cyclization units from both synthetic peptides and when linear precursors are appended onto a phage-coat protein. Given that the employed conditions are compatible with phage display protocols, our work paves the way for the selection of natural-product-like MPs from randomized peptide sequences by phage display.
\end{abstract}




\section{INTRODUCTION}

Macrocyclic peptides (MPs) hold great promise for the discovery of lead compounds in drug discovery efforts and the development of chemical probes to interrogate biological functions. ${ }^{[1]}$ When compared to their linear counterparts, MPs combine several features that make them attractive for potential applications in the clinic and in research labs: ${ }^{[2]}$ (1) cyclization of linear peptides restricts their conformational flexibility and reduces the entropic penalty upon binding to a biological target; (2) MPs cannot only target well-defined binding pockets, but also disrupt protein-protein interactions with high affinities and selectivities; and (3) short MPs ( $<15$ amino acids) elicit a low immune response and display good stability against protease degradation. The presence of a plethora of MPs in nature, where their biosynthesis bestows a competitive advantage to producing organisms, further attests on the versatile nature of MPs as bioactive compounds. ${ }^{[3]}$ For example, thiostrepton or nosiheptide are produced by fungi to keep bacterial populations in check, while the biosynthesis of $\alpha$-amanitin in the death cap mushroom renders its consumption toxic (Fig. 1A). ${ }^{[4]}$

Critically, MPs found in nature are the result of evolutionary algorithms that fine-tuned both their amino acid sequences and the posttranslational processes for the introduction of nonpeptidic moieties as cyclization units. Mimicking such a chemogenetic optimization process in the laboratory is desirable, yet challenging as the vast majority of synthetic strategies that facilitate peptide diversification and/or macrocyclization are not compatible with the biological strategies used to select binders from genetically-encodable peptide libraries. ${ }^{[5]}$ A seamless integration of cyclization strategies with biological selection approaches is critical though, as they provide a rapid means to identify MP binders from vast libraries with $10^{8}-10^{13}$ members, thus circumventing the laborious alternative of synthesizing and assessing MPs one-by-one. ${ }^{[6]}$ Among available in vitro and in vivo selection strategies, phage display has proven a robust platform for the identification of peptide-binders, as randomized linear peptides can readily be 

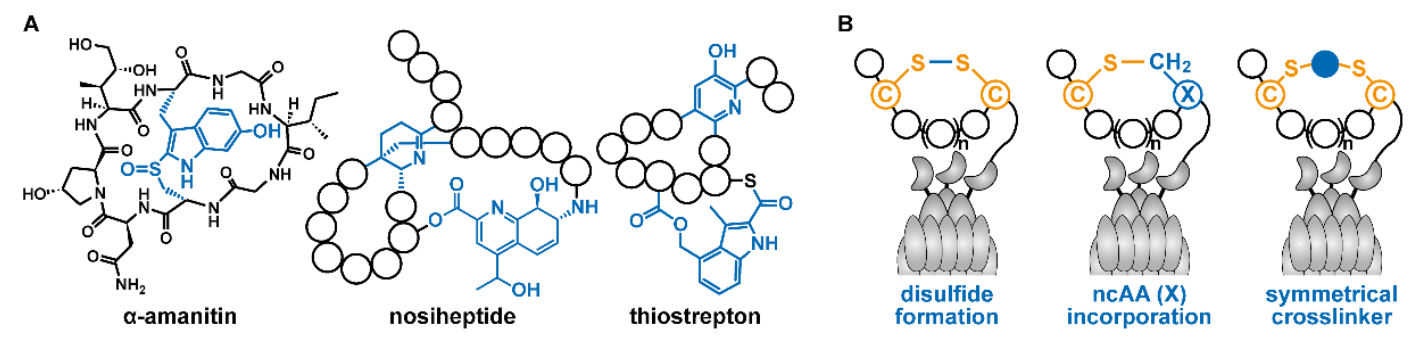

C

Figure 1. A: Structures or representations of naturally-occurring MPs, with (non-peptidic) asymmetric cyclization units highlighted in blue. B: Schematic overview of peptide-cyclization strategies compatible with phage display. Molecules that crosslink two or more of the same amino acid must be symmetric to avoid the formation of stereoor regio-isomers. C: The programmed modification of two distinct functional groups, here a unique thiol and an $\mathrm{N}$-terminal amine, alleviates symmetry constraints for cyclization units and enables the incorporation of asymmetric molecular scaffolds.

appended onto phage coat proteins. ${ }^{[7]}$ Thus far, cyclization strategies that enable the selection of MPs are limited to the formation of disulfides, ${ }^{[8]}$ the introduction of non-canonical amino acids (ncAAs) with uniquely reactive handles that trigger the spontaneous macrocyclization, ${ }^{[9]}$ or the action of small molecule cross linkers (Fig. 1B). ${ }^{[10]}$ Phage-compatible approaches for the latter have been pioneered by the Heinis and Derda groups, who created MP libraries by the reaction of two or three cysteine side chains with symmetric lynchpin molecules that feature weak electrophilic groups (e.g. di-/tri-bromomethylbenzenes or bromo-/chloro-acetamides). ${ }^{[11]}$ In these approaches, the use of crosslinkers with two- or three-fold symmetry is critical to prevent the unwanted formation of regioisomers and/or diastereomers. ${ }^{[12]}$ Unfortunately, these constraints prevent the straightforward incorporation of asymmetric molecular scaffolds, which are often found in natural MPs (Fig. 1A), where they are critical for fine-tuning pharmacological properties and improve binding to protein targets.

To meet this challenge, we describe an efficient strategy for the cyclization of displayed peptides with asymmetric cyclization units that is compatible with phage display (Fig. 1C). Specifically, we make use of a selective side-chain-to-tail cyclization following an initial cysteine alkylation step with diverse molecular scaffolds. Notably, the resulting naturalproduct-like MPs provide access to a yet unexplored chemical space from which new binders against biological targets can be selected. 


\section{RESULTS AND DISCUSSION}

Accessing well-defined MPs through the incorporation of asymmetric molecular scaffolds instead of symmetric crosslinkers necessitates the programmed modification of two distinct functional groups with orthogonal reactivity in a peptide or protein substrate. Besides making use of a uniquely reactive cysteine thiol, such approaches typically rely on the incorporation of ncAAs to install an orthogonal handle for a second modification. ${ }^{[13]}$ Most notably, the Fasan group has accessed conformationally-constrained organo-peptide hybrids in bacteria via such a tandem chemoselective reaction between synthetic molecules and genetically-encoded peptides. ${ }^{[14]}$ However, as in addition of requiring ncAAs these strategies also rely on inteins for the generation of reactive thioester intermediates, they cannot readily be adapted for phage display.

To enable the formation and selection of such organo-peptide hybrids on whole bacteriophages, we reasoned that peptides and/or proteins with a unique cysteine residue and a nearby N-terminal amine should readily undergo cyclization in presence of bifunctional cyclization units featuring a good leaving group and an (aromatic) aldehyde (Fig. 2A). Specifically, the initial cysteine-alkylation step should bring the aldehyde moiety of the cyclization unit in close proximity to the N-terminal amine. Then, condensation of these two moieties would result in the transient formation of an iminium ion, which can be selectively and irreversibly reduced by $\mathrm{NaBH}_{3} \mathrm{CN}$ to install an amine linkage. Notably, both cysteine alkylation and reductive amination typically proceed under mild conditions and are therefore expected to be compatible with whole bacteriophages. ${ }^{[13]}$

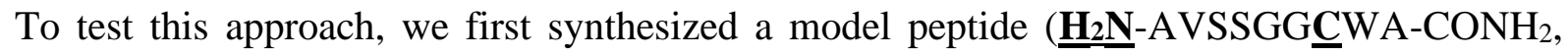
pep1) featuring a flexible sequence between the $\mathrm{N}$-terminal alanine and a unique cysteine residue as well as a tryptophan residue to allow for accurate quantification (Fig. 2B). Next, we added commercially-available 4-(bromomethyl)benzaldehyde (1, $1.5 \mathrm{mM}$ ) as a model 

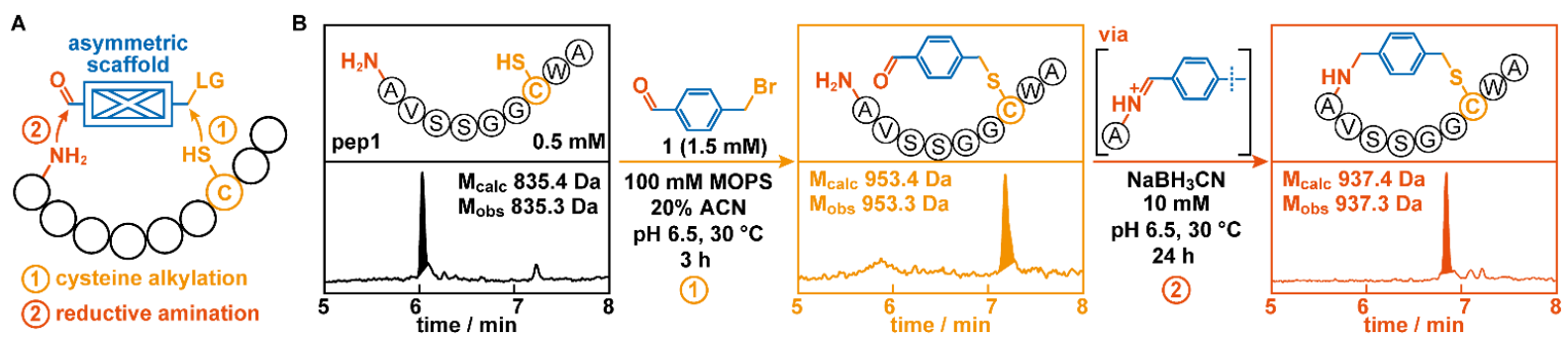

C

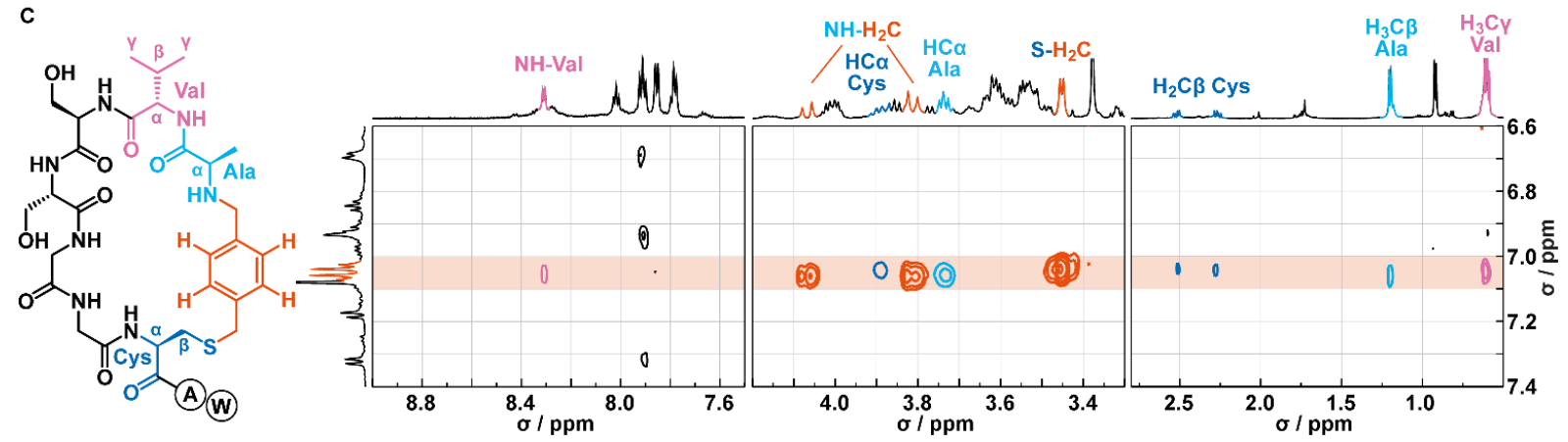

Figure 2. A: Schematic representation of the proposed two-step, side-chain-to-tail cyclization strategy. Cyclic peptides are obtained via (1) the alkylation of a unique cysteine residue and the subsequent reductive amination of a transiently formed iminium ion. B: Reaction conditions and representative examples of UPLC-MS chromatograms of synthetic pep1 (left) and crude reaction mixtures that were obtained following the modification (middle) and cyclization (right) of pep1 with 4-(bromomethyl)benzaldehyde. Total ion counts (TICs) are depicted with masses found for the highlighted, major species inserted. C: The structure of the obtained cyclic product from the reaction of pep1 with 1 as well as excerpts from a 2D NOESY spectrum are shown (see Fig. S3 for full spectrum). NOEs between the phenylic protons and amino acid residues are highlighted. Color code: phenylic protons $=$ red, cysteine protons $=$ dark blue, alanine protons $=$ light blue, valine protons $=$ magenta. Note that excerpts of the spectrum have been scaled independently to highlight the weak NOEs observed between phenylic protons and the $\mathrm{NH}-\mathrm{Val}$ as well as the $\mathrm{H}_{2} \mathrm{C} \beta$-Cys.

bifunctional cyclization unit to crude pep1 $(0.5 \mathrm{mM})$ at $\mathrm{pH} 6.5$ and followed the reaction progress by UPLC-MS. As anticipated, we observed full conversion to the cysteine-modified peptide over a period of 3 hours (Fig. 2B). The following addition of $\mathrm{NaBH}_{3} \mathrm{CN}$ (three additions, final concentration $=10 \mathrm{mM}$ ) to the reaction mixture resulted in the smooth conversion $(>90 \%)$ of the intermediate over 24 hours to a new species. Critically, the mass observed for the reaction product (-16 Da when compared to the alkylated peptide) is consistent with the cyclization occurring via the envisioned reductive amination.

To confirm the nature and connectivity of the resulting product, we recorded $1 \mathrm{D}$ and $2 \mathrm{D}$ NMR spectra for pep1 as well as for crude products obtained after cysteine-modification and the subsequent reduction step (see Supporting Information for details). Several indirect and 
direct observations confirmed the successful cyclization of pep1 with the correct side-chain-totail connectivity (Supporting Fig. S1-S2). Amongst others, we noted the splitting of protons for several methylene groups of amino acid main and side chains, which were particularly notable for the $\beta$-protons of cysteine. Moreover, in comparison to the modified intermediate, we observed the disappearance of the benzaldehyde proton in the reduced product, which was accompanied with a drastic shift of most of the amide protons. These observations are consistent with the formation of a cyclic product, which would significantly influence the environment of protons in both methylene groups and the amide backbone. Critically, when performing Nuclear Overhauser Effect Spectroscopy (NOESY) on the sample containing the crude cyclized product, we identified several interactions between $\mathbf{1}$ and the synthetic peptide that are consistent with peptide cyclization (Fig. 2C). Specifically, NOEs were not only found between aromatic protons and those of cysteine - the site of initial modification - but also with protons from the N-terminal alanine and valine residues. Similarly, we observed NOEs between the benzylic protons of the cyclization unit and those of cysteine and the $\mathrm{N}$-terminal alanine residue (Fig. S3). Combined, these experiments attest that the envisioned two-step strategy results in formation of MPs following the selective, reductive amination of a transiently-formed iminium ion.

To investigate the generality of this cyclization strategy, we prepared four additional model peptides (pep2-5, Fig. 3A). Besides varying the ring sizes that can be formed upon cyclization (pep2 and pep3), we assessed the potential cross-reactivity of amino acid side chains in the modification and reductive amination step, with a particular focus on $\varepsilon$-amines from lysine residues. As such, pep3 and pep4 feature potentially competing internal and N-terminal lysine residues respectively, while pep5 is an analogue of pep4 in which the $\mathrm{N}$-terminal amine is blocked by acetylation. Modification and cyclization reactions were performed in presence of 1 under analogous conditions as those employed for pep1 and UPLC-MS analysis confirmed 

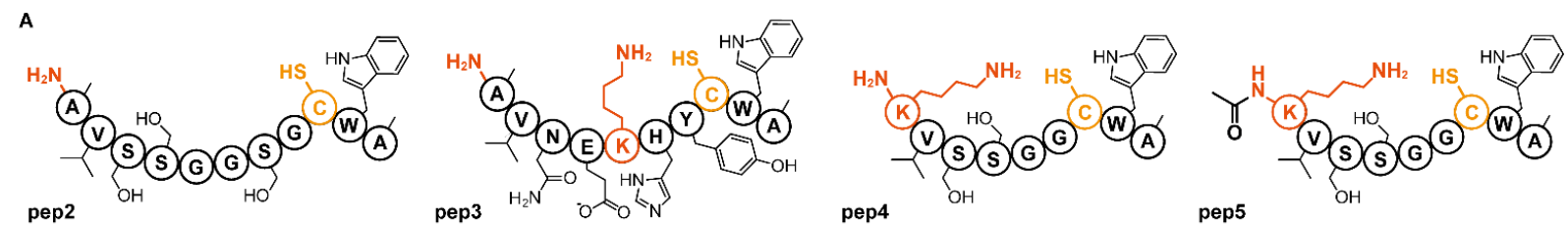

B
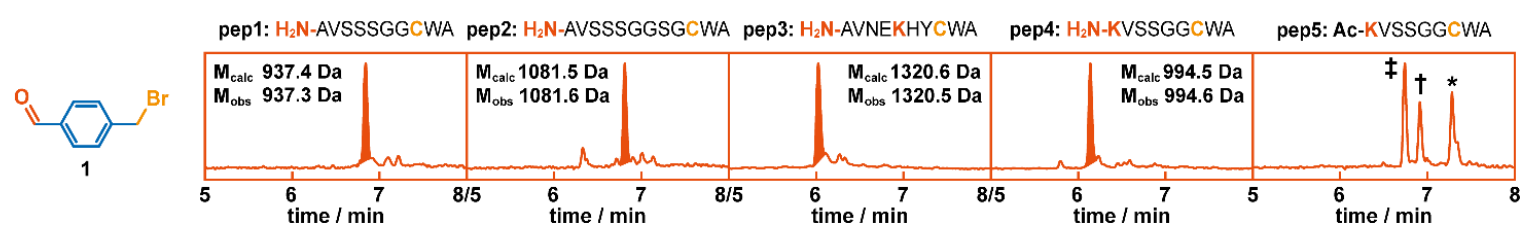

C

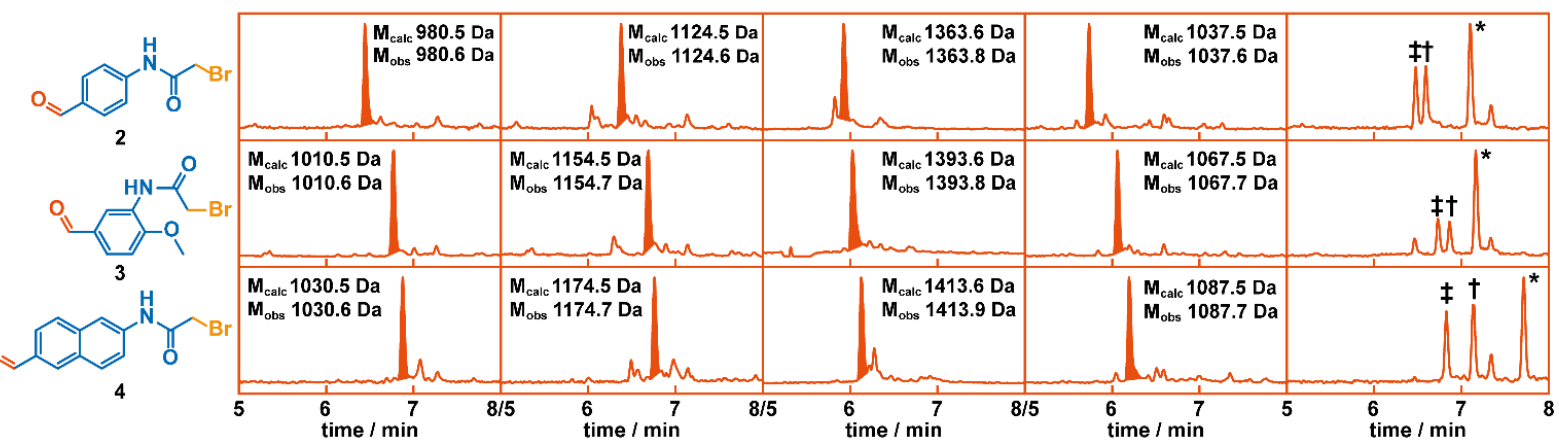

Figure 3. A: Schematic representation of model peptides used to investigate the generality of our 2-step cyclization strategy. pep1-4 vary in length and composition. N-terminal and $\varepsilon$-amines from lysine residues are highlighted in red. Note that for pep5, the N-terminal amine functionality is blocked by acetylation. B-C: Representative UPLCMS chromatograms of crude reaction mixtures obtained for pep1-5 following cyclization with cyclization units 14. Total ion counts (TICs) are depicted with masses found for the major species inserted. For pep5, the species formed are as follows: alkylated linear peptides with the aldehyde intact $(*)$ or reduced to an alcohol (†) as well as some cyclization via the lysine side-chain amine $(\$)$. UPLC chromatograms of synthetic and modified peptides are displayed in Figs. S4 and S6-S9.

the smooth conversion to the desired cyclic peptide for pep2-4 (Fig. 2C and Fig. S4). Subjecting the crude reaction product of pep4 to a 1D and 2D NMR analysis further indicated the formation of a MP via the N-terminal amine rather than that of the lysine side-chain (Fig. S5). Specifically, we observed NOEs between protons of the cyclization unit and the $\alpha$ - and $\beta$-carbons of the Nterminal lysine but not with protons from the $\gamma$ - $\varepsilon$ positions. Consistent with the unique reactivity of the N-terminus, upon its acetylation the reduction step proceeded sluggishly. Specifically, pep5 afforded a mixture of alkylated linear peptides with the aldehyde intact or reduced to the corresponding alcohol, as well as some MP resulting from cyclization via the lysine side-chain amine. This selectivity of $\mathrm{N}$-terminal over $\varepsilon$-amines of lysine residues is consistent with the 
increased nucleophilicity of the N-terminus under neutral conditions, which has been previously exploited for the selective $\mathrm{N}$-terminal modification of peptides and proteins. ${ }^{[15]}$

One notable advantage of the programmed modification of two functional groups in a peptide is the ability for the incorporation of asymmetric molecular scaffolds and avoid the formation of regioisomers that are observed when using traditional crosslinking strategies. ${ }^{[12]}$ To showcase this aspect, we synthesized three bifunctional, asymmetric cyclization units (2-4, see Supporting Information for details) that in addition to the benzaldehyde functionality featured an electrophilic bromoacetamide moiety. When subjecting pep1-4 to our cyclization protocol, all three linkers underwent efficient conversion to the corresponding MPs (Fig. 3C and Fig. S6-8). Once again, only pep5, for which the N-terminal amine is blocked by acetylation, gave rise to the same mixture of products observed with 1 (Fig. S9). Together, these results demonstrate the generality of our strategy for the cyclization of synthetic peptides with a set of bifunctional cyclization units. Notably, the efficient formation of MPs when following this two-step protocol proved independent of the amino acid sequence and the cyclization unit used.

While encouraging, the results obtained for the cyclization of synthetic model peptides do not accurately reflect the challenges associated with achieving chemo- and regioselective modification of linear peptides displayed on bacteriophages, which is a prerequisite for the application of this strategy in biological selections. Toward this end, a sequence encoding for the peptide $\underline{\mathbf{H}_{2} \mathbf{N}}$-AVSSGG $\underline{\mathbf{C}}$ was appended to the N-terminus of the soluble D1D2-domains of a cysteine-free phage-coat protein III (pIII, Fig. 4A). ${ }^{[16]}$ Additionally, we inserted the recognition site for the Tobacco Etch Virus (TEV) protease between the appended peptide and the D1D2 domains, in order to identify cyclized peptides following proteolysis (see Supporting Information for details). The resulting C-terminally, His6-tagged protein pep-TEV-D1D2 was 

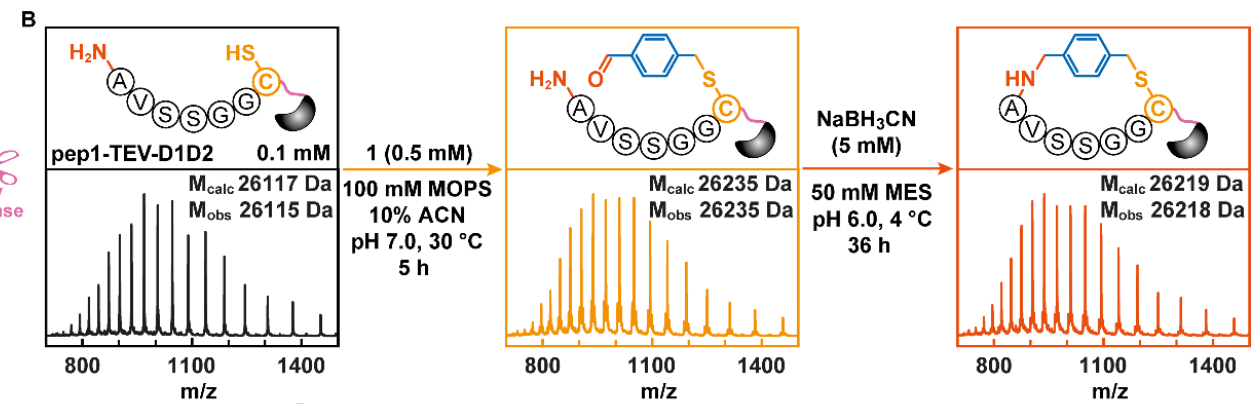

C

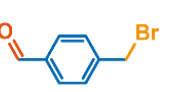

D
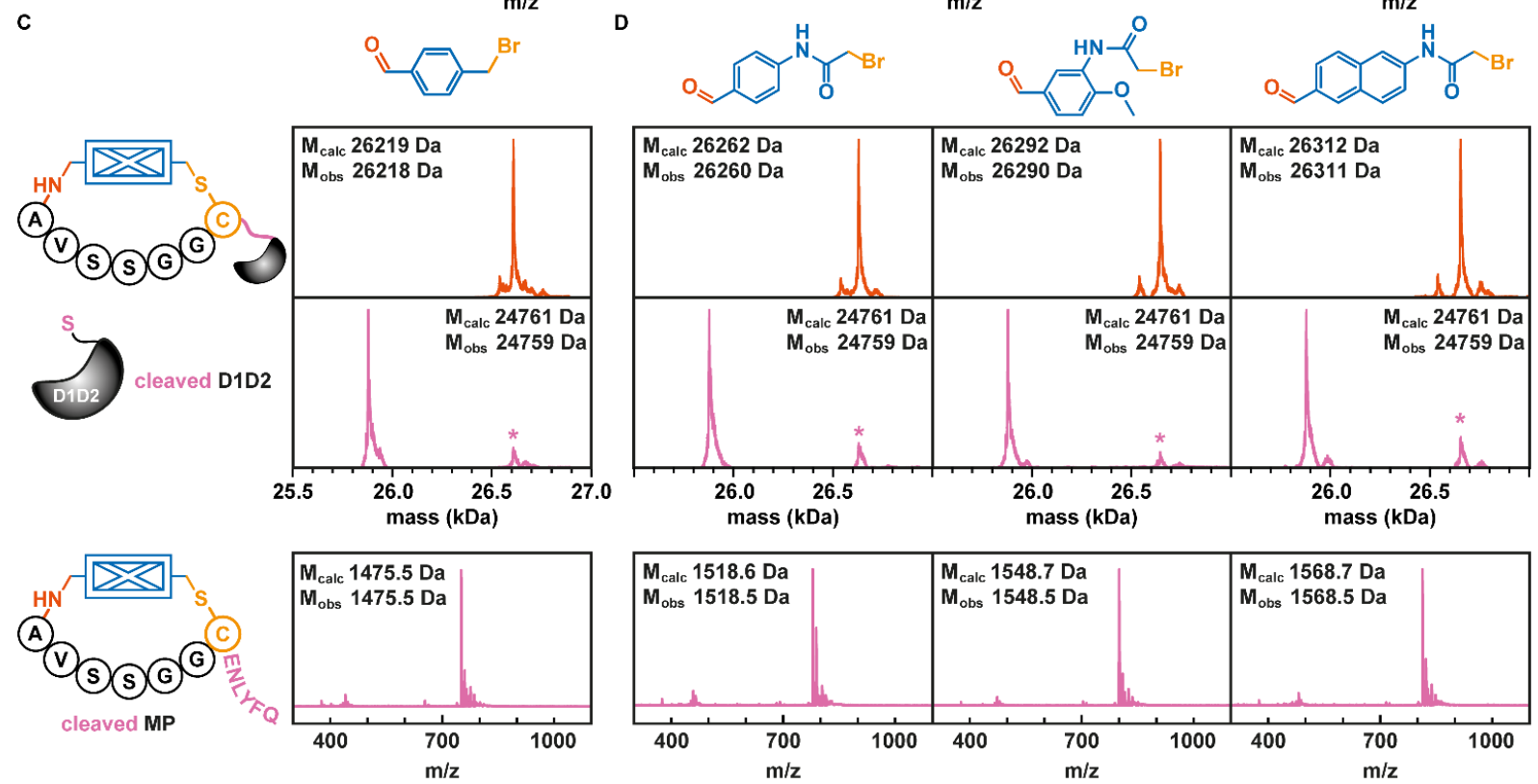

Figure 4. A: Schematic representation of the soluble D1D2-domain of the fd bacteriophage. In this work a peptide featuring a unique cysteine residue followed by the recognition site for the TEV protease was installed. The latter enables the cleavage of MPs following the two-step cyclization approach. B: Reaction conditions employed for the cyclization of peptides on soluble D1D2 domains as well as representative raw mass spectra obtained for the purified protein and crude reaction mixtures of proteins following modification and cyclization. C-D: Deconvoluted mass spectra of protein fragments before (top) and after TEV cleavage (middle) following the cyclization of pep-TEV-D1D2 with bifunctional cyclization units 1-4. Peaks labelled with a * denote pep-TEVD1D2 species that have cyclized but did not undergo cleavage. For raw mass spectra of protein fragments before and after TEV cleavage see Fig. S10 and S12. Mass spectra obtained for the cleaved cyclic peptides $(+2$ species are shown) are displayed in the bottom.

subsequently produced in Escherichia Coli, purified by $\mathrm{Ni}^{2+}$-affinity chromatography (yield $\sim 100 \mathrm{mg} / \mathrm{mL}$ ) and its identity and purity confirmed by SDS-PAGE and UPLC-MS (Fig. 4B).

Addition of the bifunctional cyclization unit $\mathbf{1}(0.5 \mathrm{mM})$ to purified and reduced pep-TEVD1D2 $(0.1 \mathrm{mM})$ at $\mathrm{pH} 7$ resulted in its conversion to a single, modified product over $5 \mathrm{~h}$ at $30^{\circ} \mathrm{C}$ (Fig. 4B and Fig. S10). Following removal of excess 1 by size exclusion and concomitant buffer exchange (to $\mathrm{pH} 6$ ), this intermediate underwent quantitative conversion (>95\%) upon 
addition of $\mathrm{NaBH}_{3} \mathrm{CN}$ (5 additions over 24 hours, final concentration $=5 \mathrm{mM}$ ) to a species with a mass that is consistent with cyclization of the appended peptide sequence. Conversely, when performing the same procedure with the parent, cysteine-free D1D2 variant, we did not observe any appreciable levels of modification throughout the procedure (Figure S11). To verify that the cyclization of pep-TEV-D1D2 took place selectively via its N-terminal amine, we added TEV protease to the crude reaction mixture and analyzed the resulting cleavage products by UPLC-MS (Fig. 4C and Fig. S10). Consistent with the high degree of selectivity observed in the model peptides, the only two species we detected following the addition of TEV protease were those with masses corresponding to (1) the cleaved protein and (2) the cyclic peptide. Comparable results were obtained when using bifunctional cyclization units $\mathbf{2 - 4}$, which all yielded cleaved MPs following cysteine alkylation, reductive amination and TEV protease treatment (Fig. 4D, Fig. S10).

Notably, in these experiments we were unable to detect either appreciable levels of double modified pep-TEV-D1D2 or instances of the cyclization taking place via a lysine side chain. With all 8 lysine residues in D1D2 being C-terminal of the TEV cleavage site, competing cyclization reactions would result in an intact pep-TEV-D1D2 species with a +18 Da-mass peak following amide hydrolysis. We ascribe the lack of double modification and the high selectivity for the N-terminus to the removal of excess linker by size exclusion following the initial cysteine alkylation step. As imine formation is reversible, aldehydes prone to condense with primary amines are therefore removed prior to the reduction step, resulting in singly cysteinemodified proteins. At this stage, the aldehyde of the cyclization units can only condense with the nearby $\mathrm{N}$-terminal amine (= proximity driven), facilitating the efficient conversion of appended, modified peptides to their cyclic counterparts.

To find application in the selection of natural-product-like MPs by phage display, we investigated whether the conditions employed for our side-chain-to-tail cyclization are 
compatible with the life cycle of bacteriophages. Toward this end, we inserted the disulfidefree D1D2 domains of pIII featuring the model peptide sequence into the fd bacteriophage genome and produced virions following established protocols (see Supporting Information for details). ${ }^{[11 \mathrm{~d}]}$ We reproducibly observed $10^{12}-10^{13}$ infective phage particles in the supernatant when producing the resulting fd bacteriophages from commercially-available E. coli TG1 cells (Fig. 5).
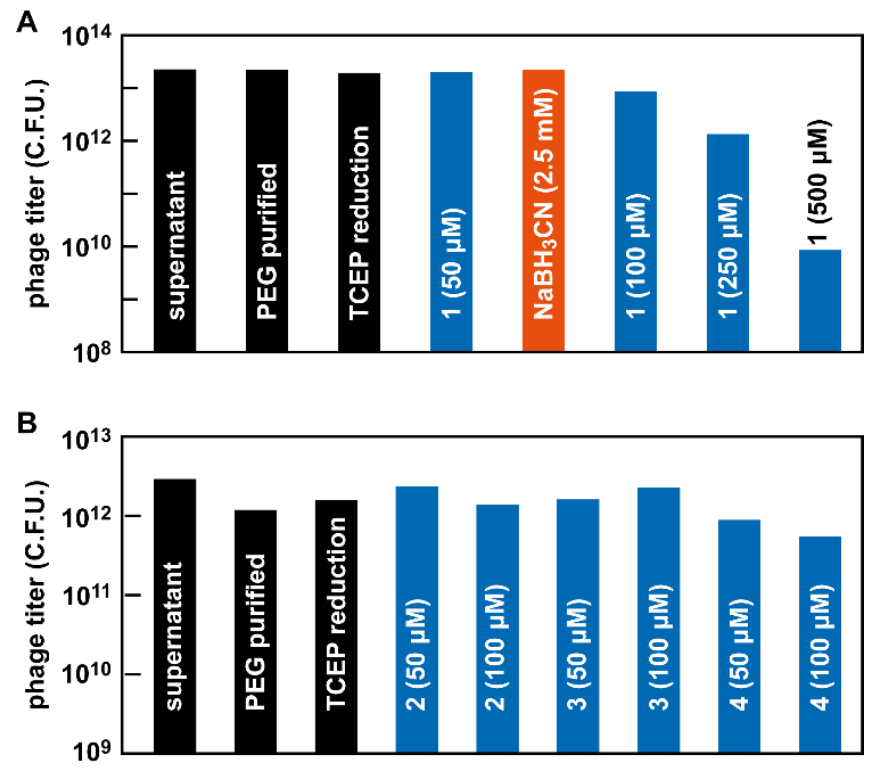

Figure 5. A-B: Phage titers measured as colony forming units (CFUs) when subjecting bacteriophages produced from E. coli TG1 cells to the two-step cyclization protocol. Bifunctional cyclization units (up to $100 \mu \mathrm{M}$ ) and $\mathrm{NaBH}_{3} \mathrm{CN}$ have a negligible effect on the life-cycle of bacteriophages and give rise to comparable phage titers as those obtained after $\mathrm{NaCl} / \mathrm{PEG}$ precipitation and TCEP reduction.

With the appropriate bacteriophages in hand, we measured the infectivity of phage particles (=phage titers in colony forming units (CFUs)) throughout all steps necessary for peptide cyclization (see Supporting Information for details). Neither purification by NaCl/PEG precipitation nor the addition of TCEP to reduce any disulfides formed during phage production resulted in a significant drop of infective phage particles when compared to the number present after their initial production. Gratifyingly, at $30{ }^{\circ} \mathrm{C}$ neither the addition of $\mathbf{1}(50 \mu \mathrm{M})$ at $\mathrm{pH} 8$ for 1 hour nor of $\mathrm{NaBH}_{3} \mathrm{CN}$ ( 5 additions, final concentration $=2.5 \mathrm{mM}$ ) at $\mathrm{pH} 6$ over 24 hours at $4{ }^{\circ} \mathrm{C}$ had a significant impact on infectivity levels (Fig. 5a). We chose $\mathrm{pH} 8$ for the initial 
cysteine alkylation as these conditions have previously been used for comparable modifications on peptide-displayed libraries. ${ }^{[11 \mathrm{~d}]}$ Only upon increasing the concentration of $\mathbf{1}$ above $250 \mu \mathrm{M}$, we observed a $\sim 10$-fold decrease in CFUs following incubation at $\mathrm{pH} 8$ at $30{ }^{\circ} \mathrm{C}$ for 1 hour (Fig 5a). Lastly, the addition of bifunctional cyclization units $\mathbf{2 - 4}$, which feature electrophilic bromoacetamide moieties, equally had no apparent impact on phage infectivity at concentrations up to $100 \mu \mathrm{M}$ (Fig. 5B).

Combined, these results are consistent with previous reports that independently found no significant impact on phage infectivity

upon addition of either electrophilic crosslinkers or $\mathrm{NaBH}_{3} \mathrm{CN}$ to modify peptides on whole bacteriophages. ${ }^{[11 \mathrm{~d}]}\left[{ }^{[17]}\right.$ The fact that the conditions employed for our 2-step cyclization strategy are compatible with phage display protocols augurs well for the incorporation of diverse bifunctional cyclization units for the selection of natural-product-like MPs from randomized peptide sequences in the near future.

\section{CONCLUSION}

In summary, we have developed an efficient two-step peptide cyclization method via the programmed modification of a unique cysteine thiol and a nearby $\mathrm{N}$-terminal amine. This strategy provides straightforward access to MPs starting from synthetic peptides or adequate sequences appended to proteins. The minimal requirements for bifunctional cyclization units the presence of an (aromatic) aldehyde and an appropriate electrophile - should readily be installable onto a wide variety of asymmetric molecular scaffolds. Furthermore, the transientlyformed iminium ion intermediate should lend itself to further diversification in presence of nucleophiles other than $\mathrm{NaBH}_{3} \mathrm{CN} .{ }^{[5 c, 18]}$ As a result, we anticipate that this protocol will proof valuable for accessing cyclic analogs of existing bioactive $\mathrm{MPs},{ }^{[5 \mathrm{a}, 5 \mathrm{~b}, 19]}$ where diverse cyclization units can be used for fine-tuning the properties of the resulting cyclic analogs. 
Combined with the compatibility of our method with whole bacteriophages, the apparent efficiencies with which peptide sequences appended to whole proteins are converted to their cyclic analogs encourages the application of this strategy to phage display in the near future. Particularly, the ability to incorporate asymmetric scaffolds promises a chemogenetic optimization akin to the evolutionary processes that gave rise to natural MPs. Allowing for the incorporation of non-peptidic moieties that (1) can serve as cyclization units, (2) provide interactions for binding, and/or (3) tailor pharmacological properties, we are confident that our side-chain-to-tail cyclization strategy will unlock a currently under-explored chemical space with great therapeutic potential. Being able to search this chemical space efficiently by biological selection strategies could therefore enable unprecedented opportunities for ligand diversification in drug discovery efforts. 


\section{Supporting Information}

\section{SUPPORTING DISCUSSION FOR 1D and 2D NMR EXPERIMENTS}

Figure S1: A comparison of ${ }^{1} \mathrm{H}-\mathrm{NMR}$ spectra obtained for synthetic pep1 before and after modification with $\mathbf{1}$, shows the appearance of signals consistent with the para-substituted benzene and aldehyde protons of the cyclization unit. Moreover, the two $\beta$-protons of cysteine are split in the modified sample, which is consistent with a conformational restriction upon thiol alkylation. Notably, for the ${ }^{1} \mathrm{H}-\mathrm{NMR}$ spectrum obtained following reduction with $\mathrm{NaBH}_{3} \mathrm{CN}$ individual $\beta$-protons of cysteine become even more distinct, which is consistent with cyclization. Similarly, we noted the disappearance of the aldehyde proton and the concomitant shift of one pair of aromatic protons, which are consistent with the change from the benzaldehyde to the corresponding benzylamine moiety. Similarly, we observe two new signals around 4 and $4.3 \mathrm{ppm}$, which were assigned to the benzylic protons formed upon reductive amination.

Figure S2: For the comparison of ${ }^{1} \mathrm{H}$ total correlated spectra (TOCSY) spectra between the synthetic (A), modified (B) and cyclized peptide (C), we focused on identifying significant shifts of amide protons. As amide protons form a spin-system with protons from their respective side chains, this analysis enabled us to assign individual amide protons to their corresponding amino acids in all three spectra. For example, cysteine alkylation has little effect on the environment of most amide protons, with exception to the small shifts observed for those corresponding to the C-terminal alanine, tryptophan and glycine residues (spectrum $\mathbf{A}$ and $\mathbf{B}$ ). As such, this result is indicative for an interaction of the newly installed benzene ring from the cyclization unit with these residues. In stark contrast, amide protons in the TOCSY spectrum of the reduced product have undergone drastic changes. Particularly, signals corresponding to serine and glycine residues shift by approximately $0.5 \mathrm{ppm}$. This difference is consistent with 
the formation of a cyclic product that will require these flexible amino acids to adopt different conformations. Moreover, the splitting of $\alpha$ - and $\beta$-methylene protons of glycine and serine residues, respectively can be observed, which is also consistent with the formation of a MP.

Figure S3: As stated in the main text of the manuscript, we performed Nuclear Overhauser Effect Spectroscopy (NOESY) on the crude cyclized product after modification of pep1 with 1 and subsequent reduction with $\mathrm{NaBH}_{3} \mathrm{CN}$. Note that the spectrum was recorded at a lower temperature $\left(4{ }^{\circ} \mathrm{C}\right.$ vs $\left.25{ }^{\circ} \mathrm{C}\right)$ than the ${ }^{1} \mathrm{H}-\mathrm{NMR}$ and TOCSY spectra discussed before to improve the signal-to-noise ratio of NOEs over background. In addition to the signals observed for the aromatic protons of $\mathbf{1}$ (Fig. 2C), we also identified NOEs between the benzylic protons and those of cysteine and the $\mathrm{N}$-terminal alanine residue. Particularly, this analysis revealed that the alpha and beta-protons of cysteine exclusively interact with the benzylic protons with a shift of $4.45 \mathrm{ppm}$, while the corresponding alanine protons give rise to NOEs with the second set of benzylic protons at 3.8 and $4.1 \mathrm{ppm}$. 

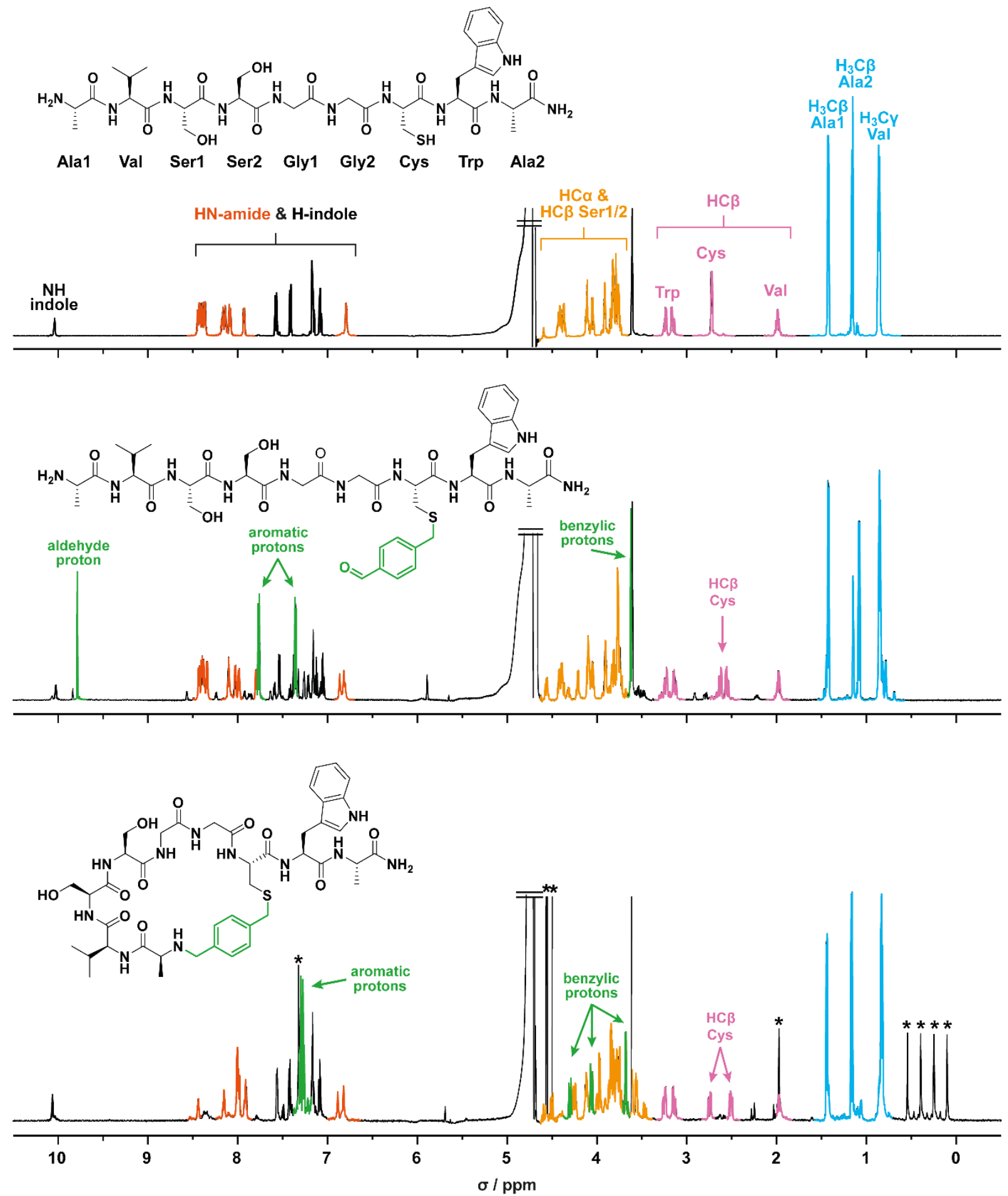

Figure S1: ${ }^{1} \mathrm{H}-\mathrm{NMR}$ of synthetic pep1, after cysteine alkylation with $\mathbf{1}$ and following cyclization in presence of $\mathrm{NaBH}_{3} \mathrm{CN}$. See Supporting Discussion for an analysis of the most relevant changes. Relevant peaks are highlighted by different colors. Peaks assigned with a $*$ are ascribed to hydrolysis/decomposition products of $\mathrm{NaBH}_{3} \mathrm{CN}$. 

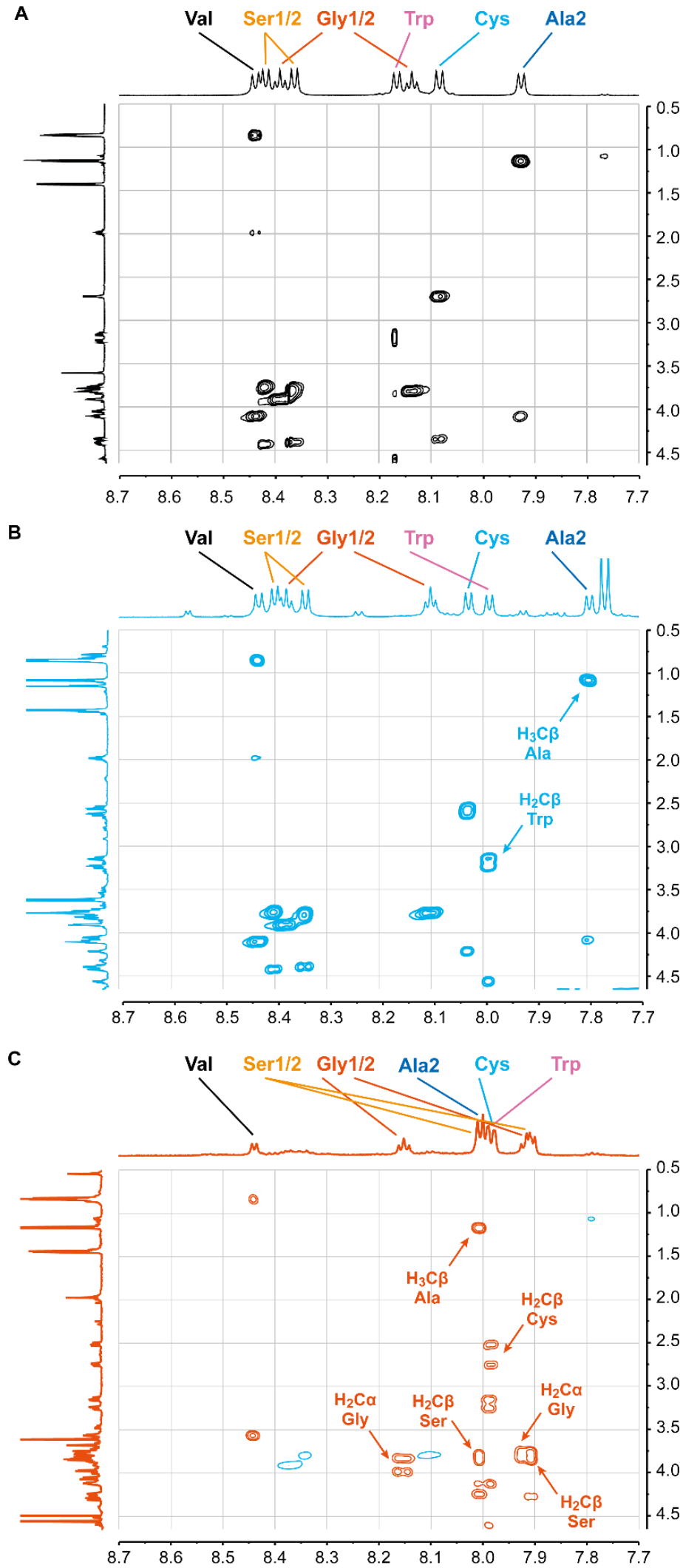

Figure S2: ${ }^{1} \mathrm{H}$-TOCSY spectra highlighting the spin systems between amide protons and amino acid side chains of synthetic pep1 (A), after cysteine alkylation with 1 (B) and following cyclization in presence of $\mathrm{NaBH}_{3} \mathrm{CN}(\mathbf{C})$. Residual signals resulting from incomplete conversion to the MP are highlighted in light blue in panel C. See Supporting Discussion for the interpretation of the most relevant changes inbetween spectra. 

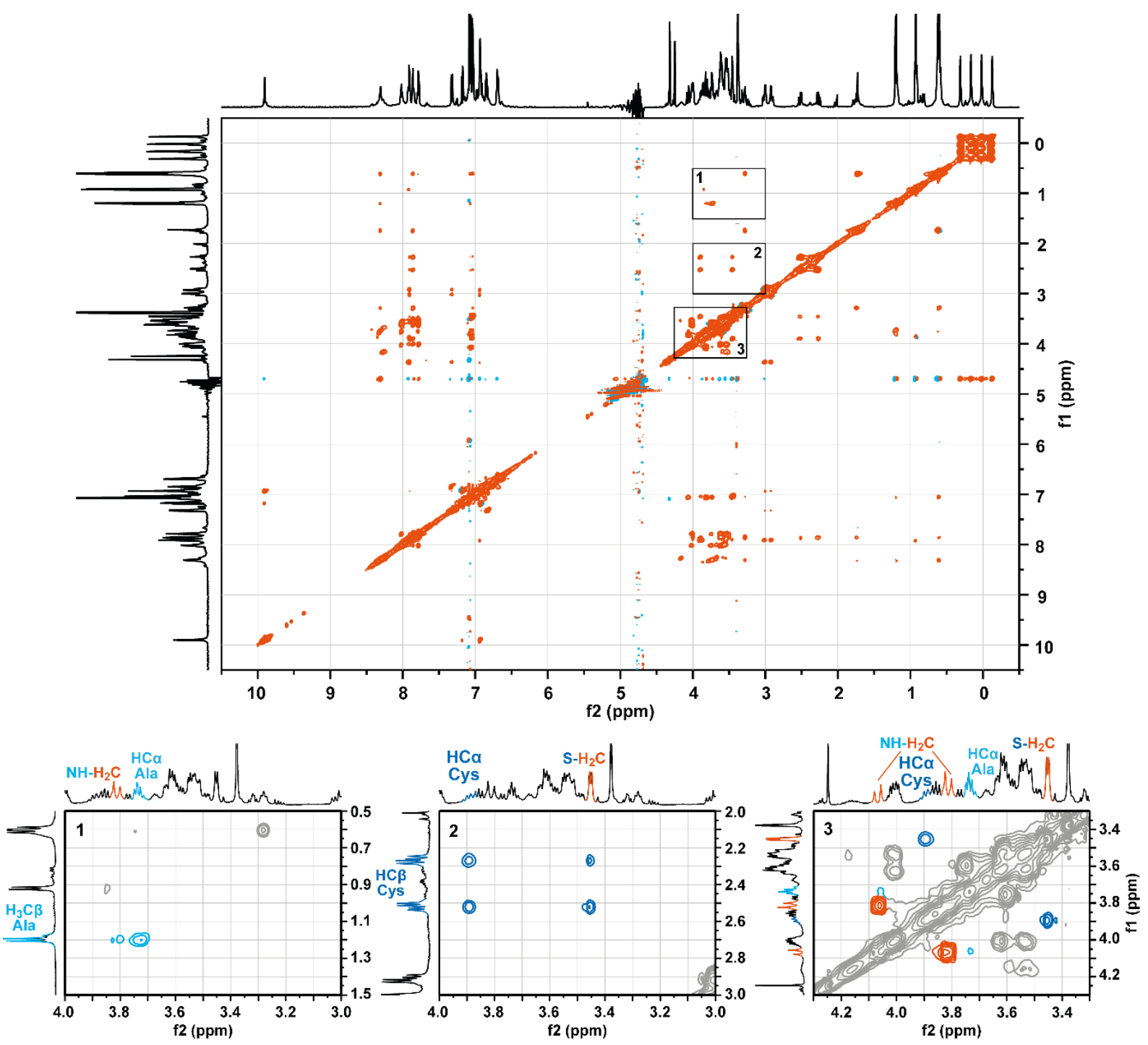

Figure S3: ${ }^{1} \mathrm{H}-\mathrm{NOESY}$ obtained from the crude reaction mixture following cyclization of pep1 with 1. Inserts show critical NOEs observed between the benzylic protons of the bifunctional cyclization unit and the $\mathrm{N}$-terminal alanine residue as well as the unique cysteine. See Supporting Discussion for the interpretation of the most relevant changes in-between spectra. 

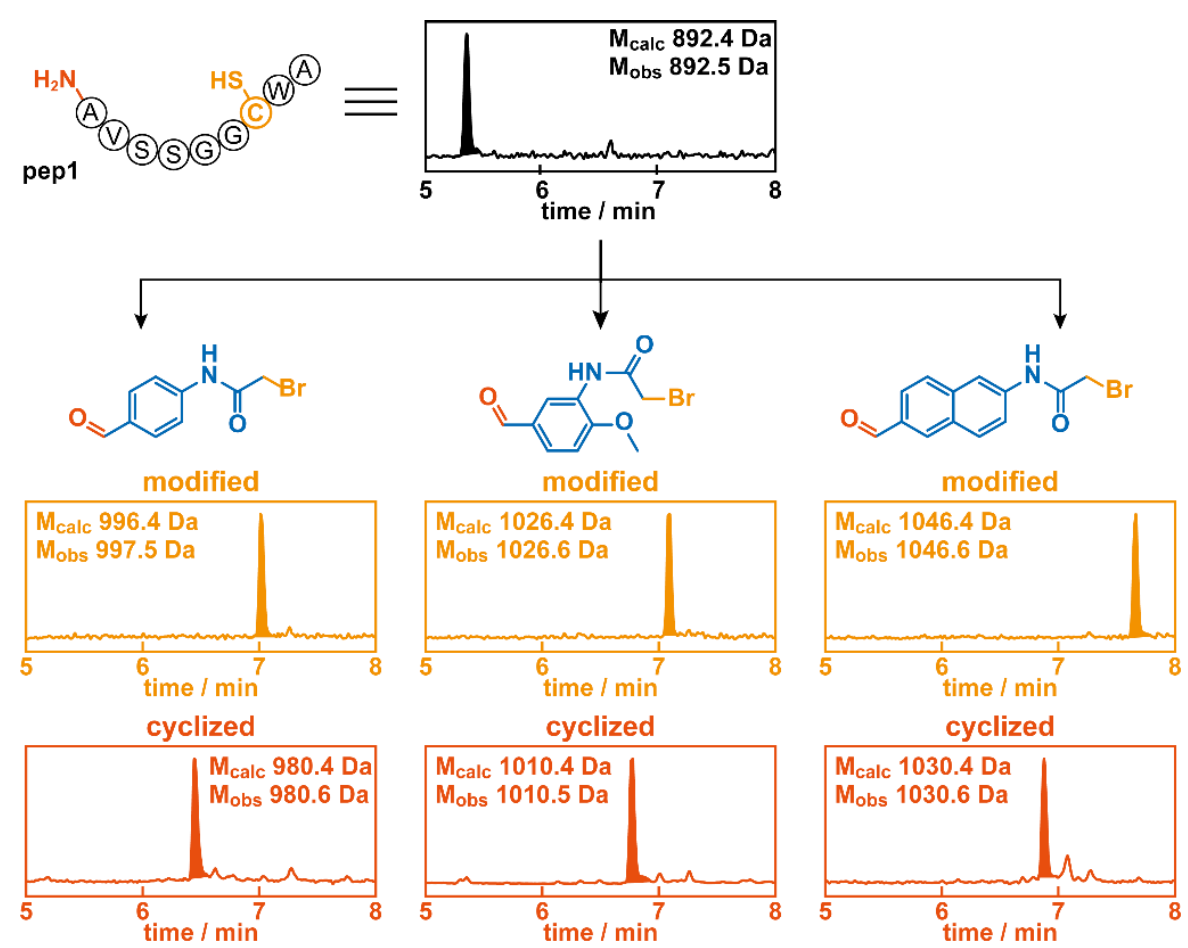

Figure S4: Representative UPLC-MS chromatograms of synthetic pep1 (top) and crude reaction mixtures obtained following reaction with bifunctional cyclization units 2-4 (middle) and cyclization in presence of $\mathrm{NaBH}_{3} \mathrm{CN}$ (bottom). Total ion counts (TICs) are depicted with masses found for the major species inserted.

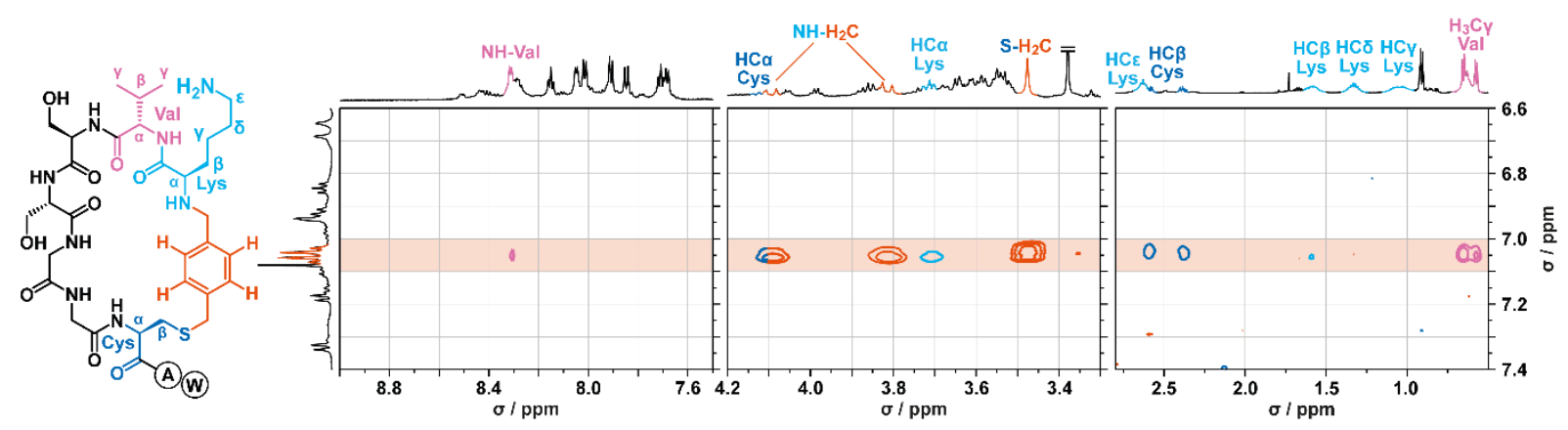

Figure S5: The structure of the obtained cyclic product from the reaction of pep4 with 1 as well as excerpts from a 2D NOESY spectrum are shown. NOEs between the phenylic protons and amino acid residues are highlighted. Color code: phenylic protons $=$ red, cysteine protons $=$ dark blue, lysine protons $=$ light blue, valine protons $=$ magenta. Critically, NOEs are only observed for the $\alpha$ - and $\beta$-protons of lysine but are absent for $\gamma-\varepsilon$ protons. This observation is consistent with the cyclization occurring selectively via the $\mathrm{N}$-terminus instead of the $\varepsilon$-amine. Note that excerpts of the spectrum have been scaled independently to highlight the weak NOEs observed between phenylic protons and the $\mathrm{NH}-\mathrm{Val}$ as well as the $\mathrm{H} 2 \mathrm{C} \beta$-Lys. 


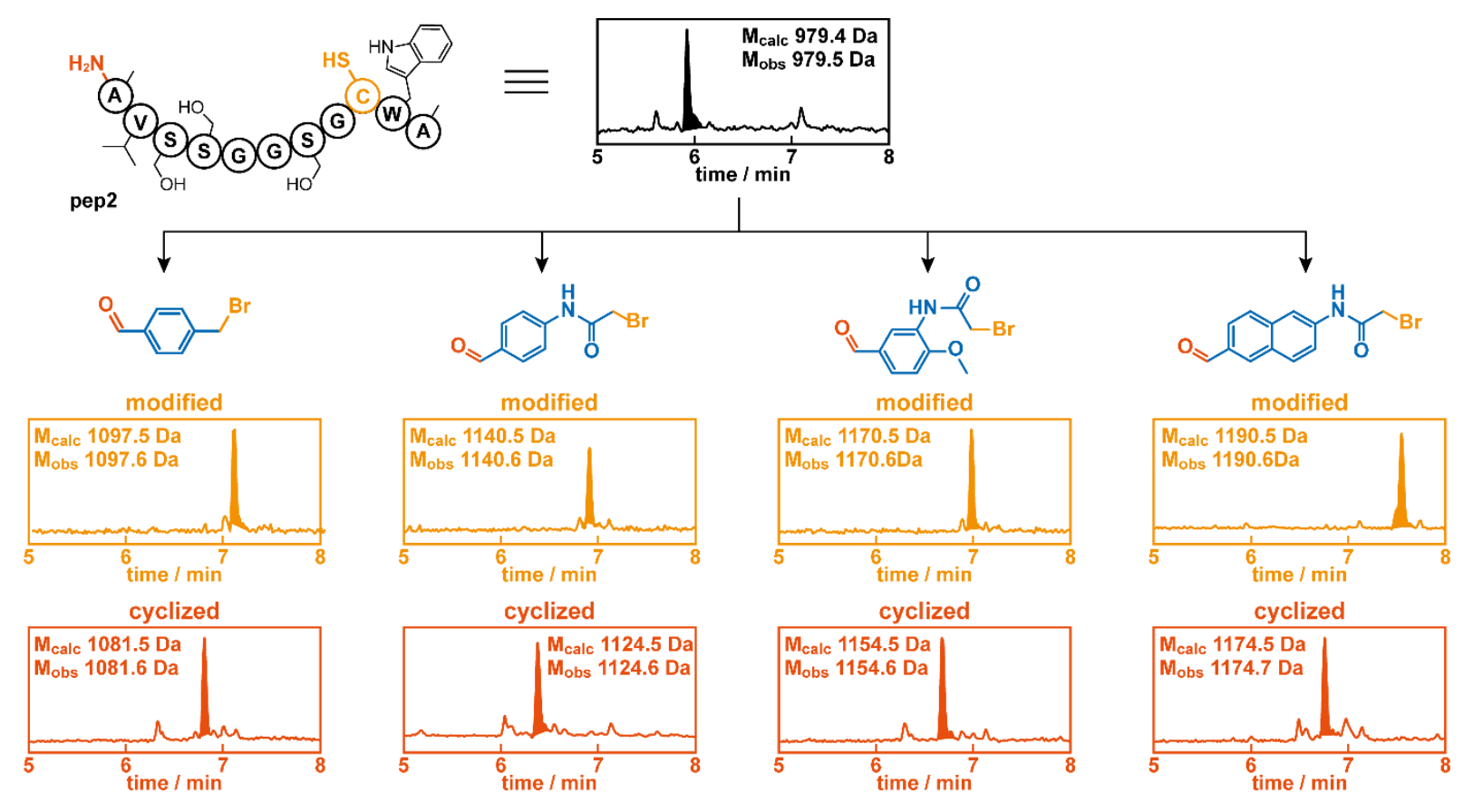

Figure S6: Representative UPLC-MS chromatograms of synthetic pep2 (top) and crude reaction mixtures obtained following reaction with bifunctional cyclization units 1-4 (middle) and cyclization in presence of $\mathrm{NaBH}_{3} \mathrm{CN}$ (bottom). Total ion counts (TICs) are depicted with masses found for the major species inserted.

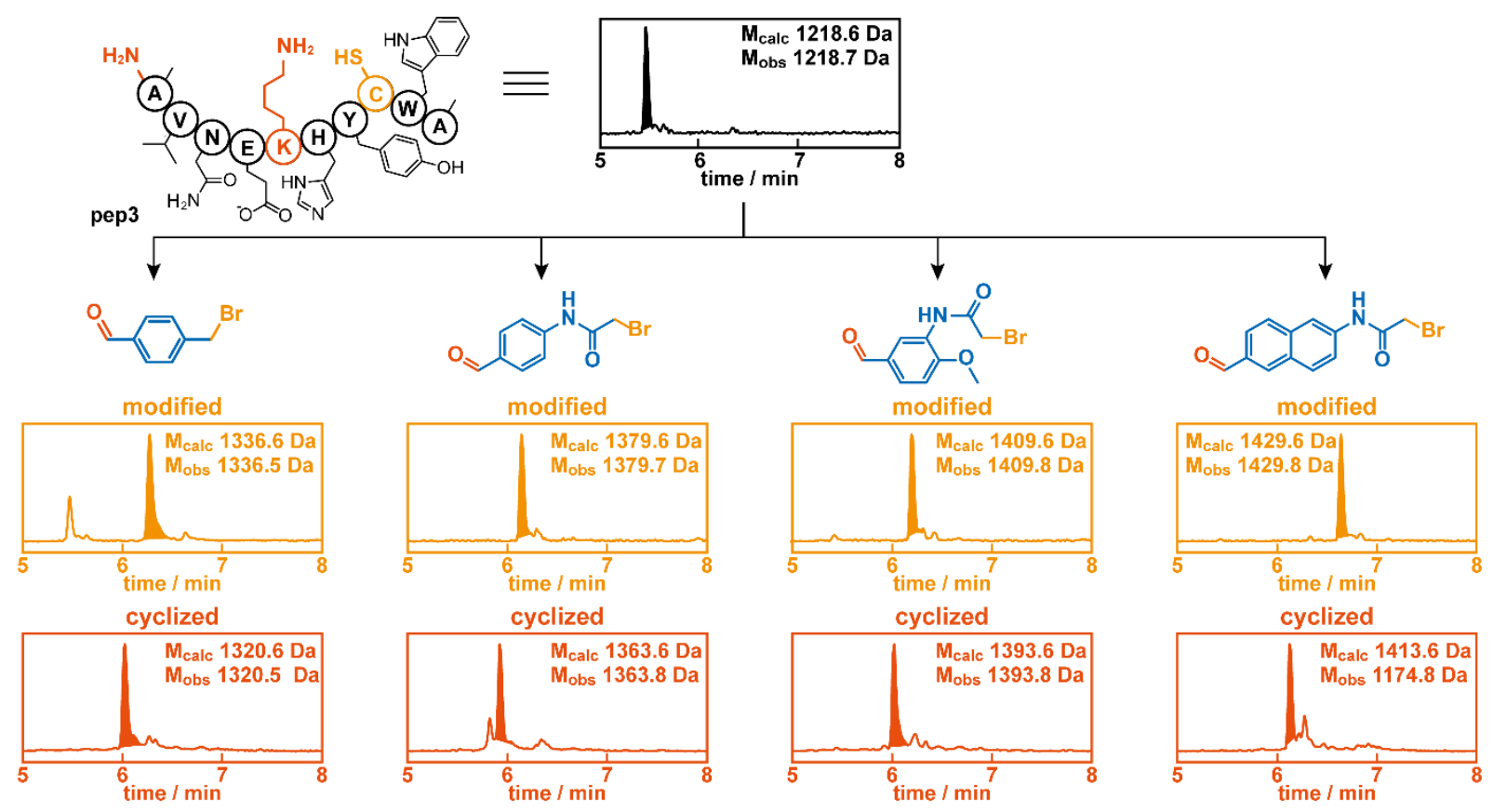

Figure S7: Representative UPLC-MS chromatograms of synthetic pep3 (top) and crude reaction mixtures obtained following reaction with bifunctional cyclization units 1-4 (middle) and cyclization in presence of $\mathrm{NaBH}_{3} \mathrm{CN}$ (bottom). Total ion counts (TICs) are depicted with masses found for the major species inserted. 


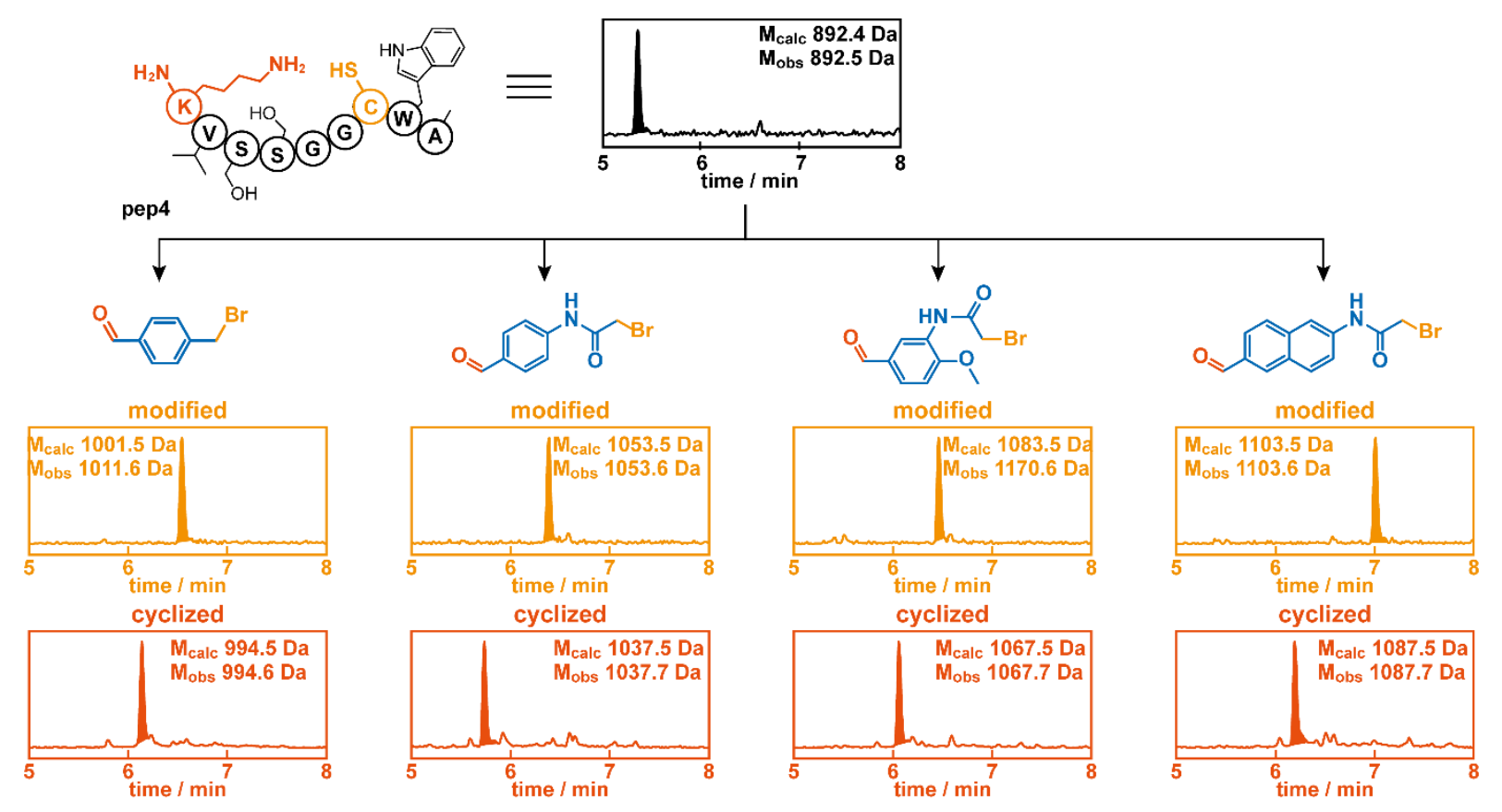

Figure S8: Representative UPLC-MS chromatograms of synthetic pep4 (top) and crude reaction mixtures obtained following reaction with bifunctional cyclization units 1-4 (middle) and cyclization in presence of $\mathrm{NaBH}_{3} \mathrm{CN}$ (bottom). Total ion counts (TICs) are depicted with masses found for the major species inserted.

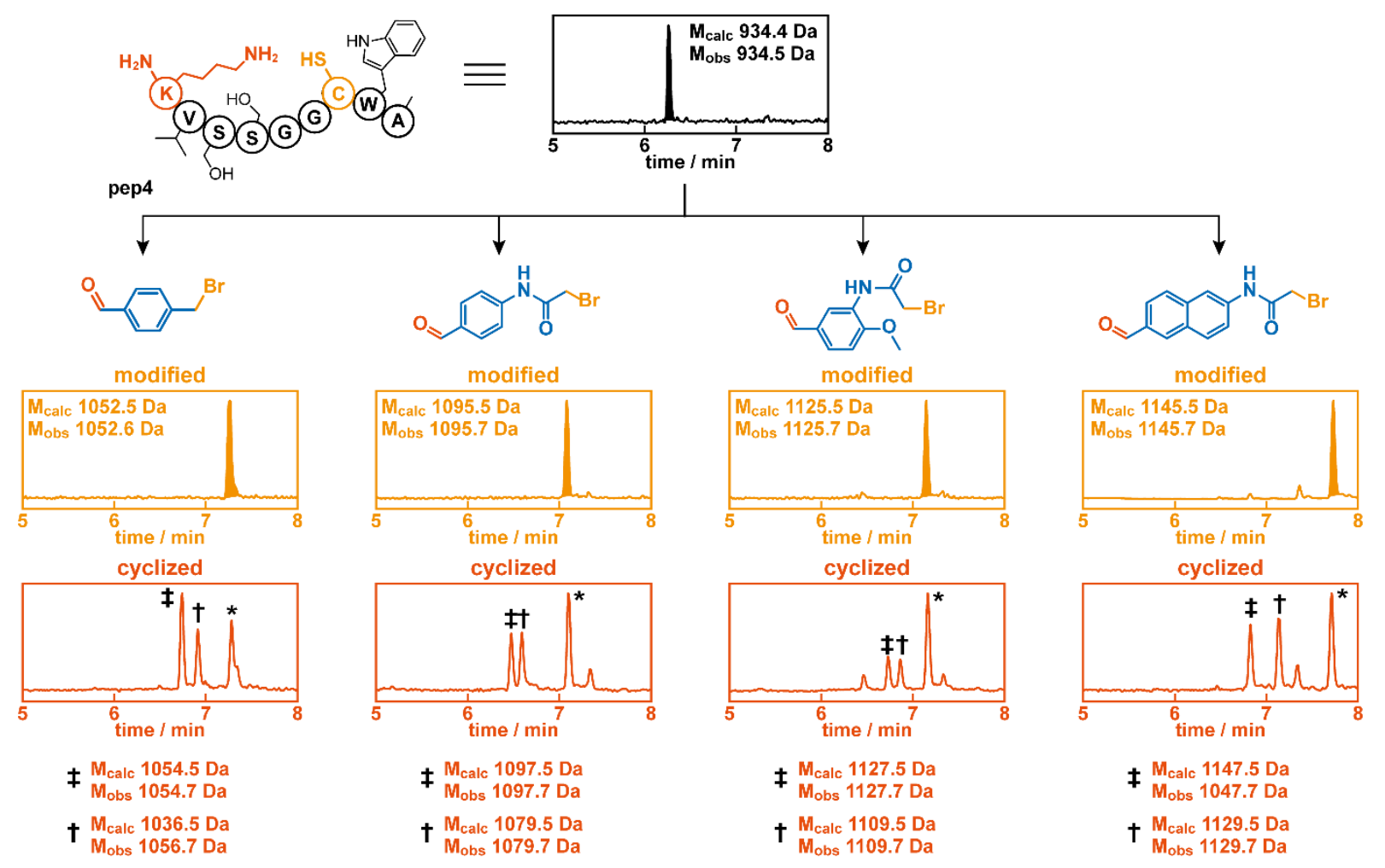

Figure S9: Representative UPLC-MS chromatograms of synthetic pep5 (top) and crude reaction mixtures obtained following reaction with bifunctional cyclization units 1-4 (middle) and cyclization in presence of $\mathrm{NaBH}_{3} \mathrm{CN}$ (bottom). Total ion counts (TICs) are depicted with masses found for the major species displayed. 
A

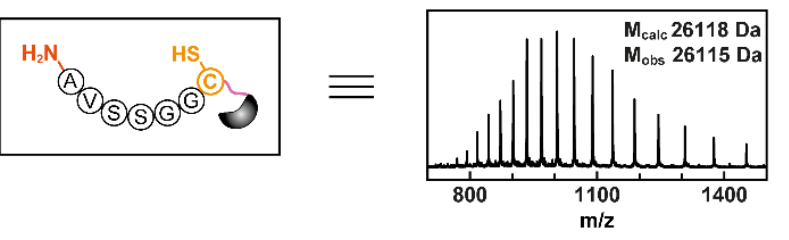

B

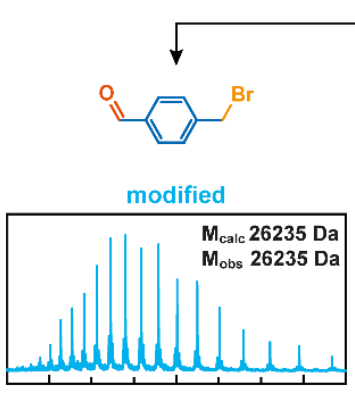

cyclized

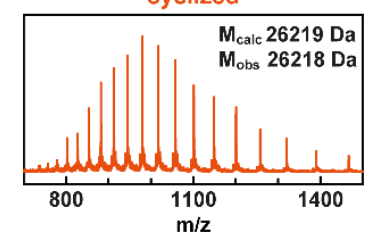

c
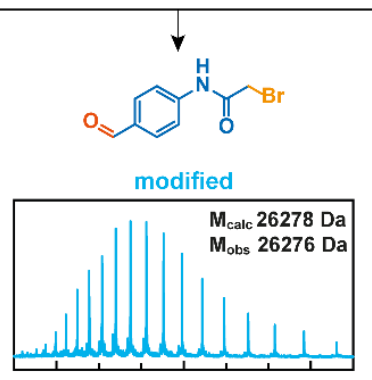

cyclized
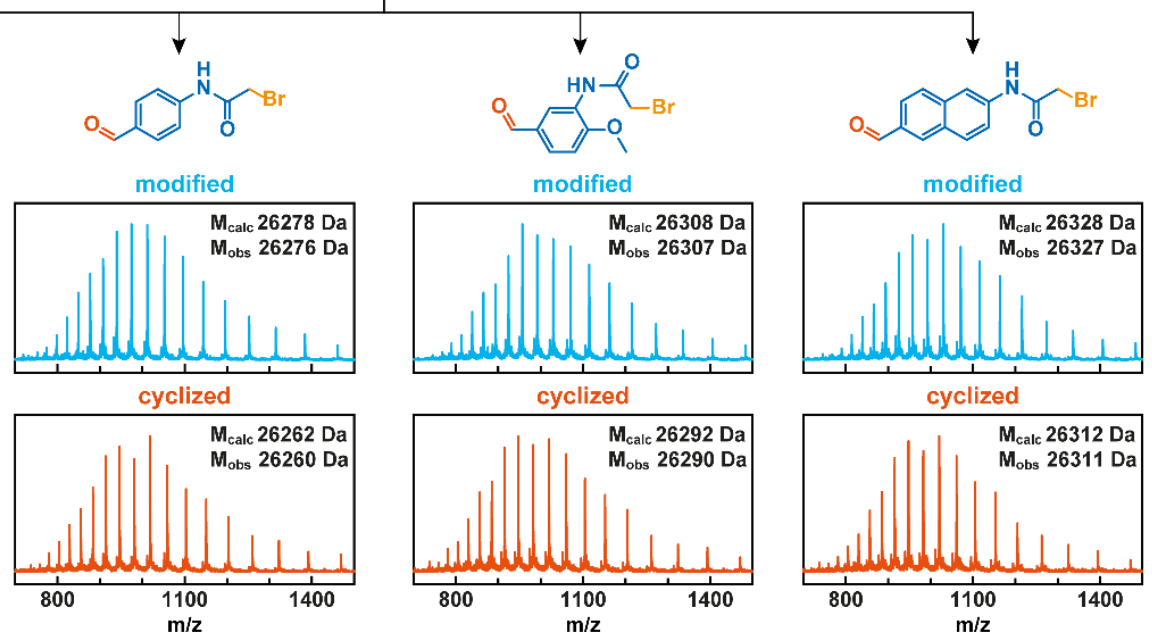

cyclized

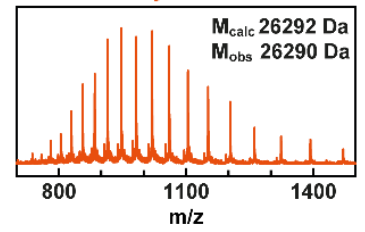

cyclized
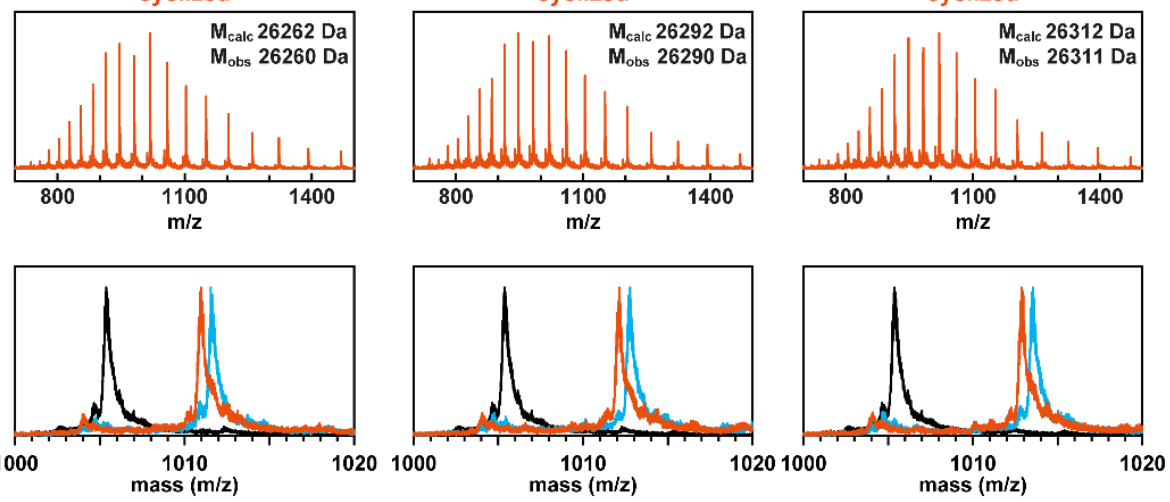

D

cleaved-D1D2
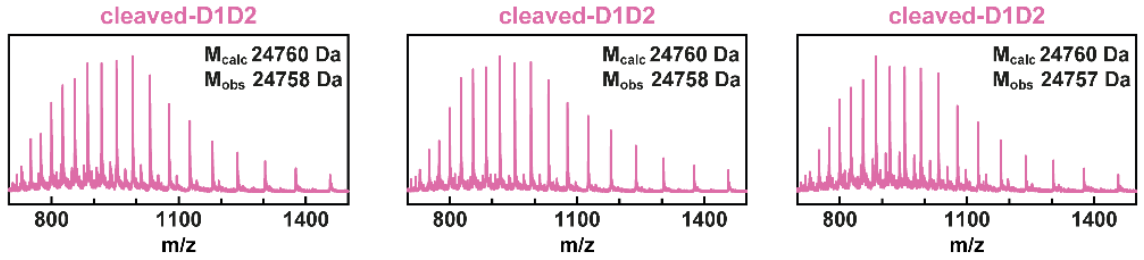

Figure S10: A-B: Representative raw mass spectrum and deconvoluted mass obtained for purified pepTEV-D1D2 (A) and crude reaction mixtures obtained following modification and cyclization with 1-4 (B). C: Zoom-in of the $+26 \mathrm{~m} / \mathrm{z}$ peak around 1000-1020 Da for pep-TEV-D1D2 (black), following modification (blue) and cyclization (red). The formation of a distinct species following reductive amination demonstrates the selective formation of cyclic peptides on pep-TEV-D1D2. D: Representative raw mass spectrum and deconvoluted mass obtained for the protein fragment following TEV protease treatment. 

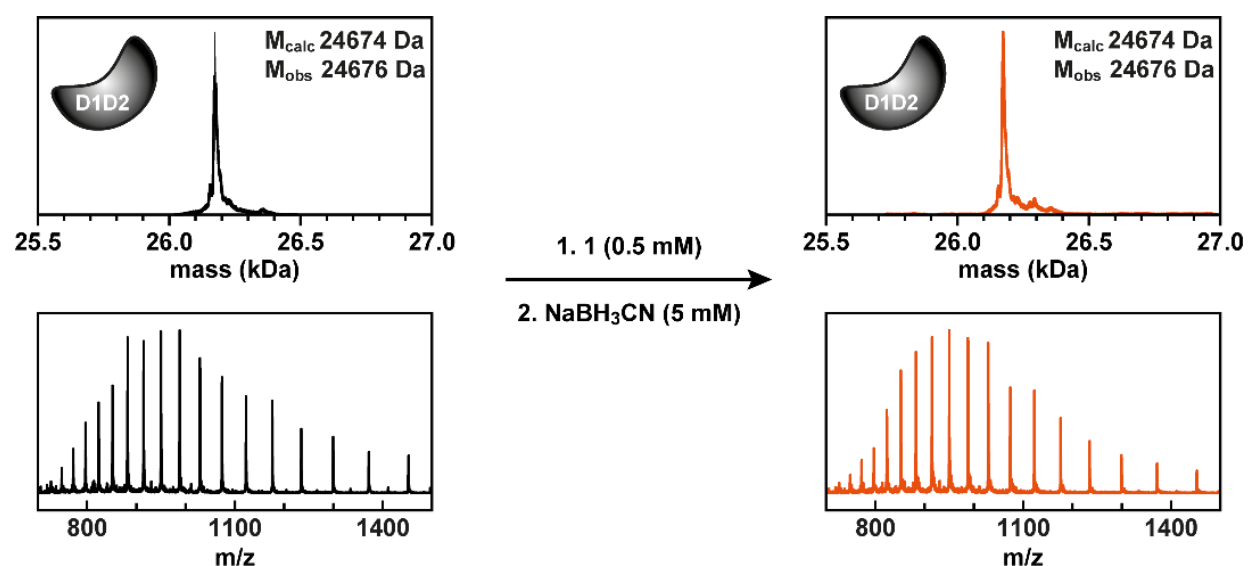

2. $\mathrm{NaBH}_{3} \mathrm{CN}(5 \mathrm{mM})$

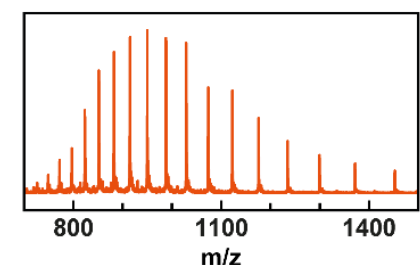

Figure S11: Representative raw mass spectra obtained for purified disulfide-free D1D2 and the crude reaction mixture following modification of D1D2 with 1 and $\mathrm{NaBH}_{3} \mathrm{CN}$ treatment. As stated in the main text, we were unable to observe any appreciable levels of modification in absence of the appended peptide. 


\section{MATERIALS AND METHODS}

Chemicals were used without further purification unless otherwise noted. All chemicals used in organic synthesis were purchased from SigmaAldrich or TCI Europe. ChemMatrix ${ }^{\circledR}$ Rink amide resin was purchased from SigmaAldrich. Solid-phase reaction vessels (syringes with filter) were purchased from Torviq. Fmoc-protected amino acids, HCTU, trifluoro acetic acid (TFA) and OxymaPure ${ }^{\circledR}$ were purchased from ChemImpex Inc. Solvents for solid phase peptide synthesis (dichloromethane (DCM) and dimethylformamide (DMF)) were purchased from Biosolve. DIPEA and piperidine was purchased from Iris Biotech GMB. Analytical thinlayer chromatography was carried out on pre-coated silica gel on aluminum sheets (Merck TLC Silica gel 60 / Kieselguhr F254), columns were performed using silica-P flash silica gel from Silicycle (0.040-0.063 mm 230400 mesh). ${ }^{1} \mathrm{H}-\mathrm{NMR}$ and ${ }^{13} \mathrm{C}-\mathrm{NMR}$ spectra were recorded on a Bruker $400 \mathrm{MHz}$ in Methanol-d4, $\mathrm{CDCl}_{3}$ or DMSO-d6. 1D and 2D NMR spectra of peptides were performed in $90 \% \mathrm{H}_{2} \mathrm{O} / 10 \% \mathrm{D}_{2} \mathrm{O} /$ trifluoroacetic acid and recorded on a Bruker $600 \mathrm{MHz}$ spectrometer. The strongest solvent peak was suppressed using excitation sculpting. Spectra were recorded either at $25{ }^{\circ} \mathrm{C}$ or at $4{ }^{\circ} \mathrm{C}$. HSQC, TOCSY, and NOESY (120 ms mixing time) spectra were performed.

Analytical UPLC-MS analysis was performed on an Acquity UPLC system (Waters) coupled to a quadrupole/time-of-flight (QToF) mass spectrometer (Waters) equipped with a PDA detector. The peptides were separated on an Acquity BEH C8; $150 \times 2.1 \mathrm{~mm}, 1.7 \mu \mathrm{m}$ (Waters) column operated at $40^{\circ} \mathrm{C}$. The eluent system employed was a combination of $\mathrm{A}(0.1 \%$ formic acid in water $)$ and $\mathrm{B}(0.1 \%$ formic acid in acetonitrile $)$ at a flow rate of $0.3 \mathrm{~mL} / \mathrm{min}$. The gradient varied linearly from 5 to $60 \% \mathrm{~B}(\mathrm{v} / \mathrm{v})$ from $0-10 \mathrm{~min} ., 60$ to $95 \%$ B from 10-11 min., kept at 95\% B from 11-13 min., returning to 5\% B in 2 min., re-equilibration to $5 \% \mathrm{~B}$ from $15-20 \mathrm{~min}$. Protein samples were separated on an Acquity BEH C4; $150 \times 2.1 \mathrm{~mm}, 1.7 \mu \mathrm{m}$ (Waters) column operated at $40^{\circ} \mathrm{C}$. The gradient varied linearly from 15 to $70 \% \mathrm{~B}(\mathrm{v} / \mathrm{v})$ from $0-10 \mathrm{~min}$., 70 to 
95\% B from 10-11 min., kept at 95\% B from 11-13 min., returning to $20 \%$ B in 2 min., reequilibration to $15 \%$ B from $15-20$ min. The sample injection volume was $3 \mu \mathrm{L}$. Mass spectra were obtained in the ESI-positive ion mode over a mass range between 500 to $1500 \mathrm{Da}$ at resolution >20.000 FWHM. Peptide samples were diluted to $100 \mu \mathrm{M}$ and protein samples were diluted to $15 \mu \mathrm{M}$ prior to analysis. Obtained charge density spectra were deconvoluted using the MagTran software. ${ }^{[20]}$

Plasmid pET21b(+), bearing the ampicillin resistance gene was purchased from Novagen ${ }^{\circ}$. Escherichia coli strain NEB10-beta (New England Biolabs) was used for cloning and Primers were synthesized by Eurofins $M W G$ Operon (Germany). Plasmid Purification Kits were obtained from QIAGEN (Germany) and DNA sequencing carried out by Eurofins (Germany). Phusion polymerase, T4 ligase, and NdeI, XhoI, Sfil, and EcoRI were purchased from New England Biolabs. Ni-NTA resin (Ni SepharoseTM 6 Fast Flow) from GE Healthcare Life Sciences (Germany). Concentrations of DNA and protein solutions were determined based on the absorption at $260 \mathrm{~nm}$ or $280 \mathrm{~nm}$ on a Thermo Scientific Nanodrop $2000 \mathrm{UV}-\mathrm{Vis}$ spectrophotometer. Theoretical molecular weights of proteins were calculated using the Expasy ProtParam tool (http://web.expasy.org./protparam/). Cellular density $\left(\mathrm{OD}_{600}\right)$ was measured on an Ultrospec 10 Cell Density Meter (Biochrom).

E. coli TG1 cells (Agilent) were used for working with bacteriophages. Phage vectors fdg3p0ss21 and fd0D1D2' were kindly provided by Prof. Christian Heinis (LPPT group, EPFL Lausanne), with permission from Prof. F.X. Schmid. Buffers and solutions: PEG/NaCl: 20\% PEG-6000 (w/v), $2.5 \mathrm{M} \mathrm{NaCl}$ (Sigma Aldrich) stored at $4{ }^{\circ} \mathrm{C}$; reaction buffer: $20 \mathrm{mM}$ HEPES, 5 mM EDTA, pH 8.0; reduction buffer: 50 mM MES, pH 6 (pH adjusted with $\mathrm{NaOH}$ and $\mathrm{HCl}$; the buffers were degassed by applying a vacuum and stirring with a magnet for $3 \mathrm{~h}$ prior to use). Reagents: tris(2-carboxyethyl)phosphine (TCEP), $20 \mathrm{mM}$ stock in $\mathrm{H}_{2} \mathrm{O}$ (stored at $4{ }^{\circ} \mathrm{C}$ for up 
to 1 month); bifunctional scaffold, $50 \mathrm{mM}$ stock in acetonitrile (prepared fresh). Amicon® Ultra-15 (100 kDa \& 30 kDa) Centrifugal Filter Units (SigmaAldrich).

\section{SOLID PHASE PEPTIDE SYNTHESIS}

Loading of Rink amide resin (coupling of Fmoc-Ala-OH: Rink amide resin loading = 0.4$0.6 \mathrm{mmol} / \mathrm{g}, 0.6 \mathrm{mmol} / \mathrm{g}$ was used as 1 eq.) was swollen in dry DMF for 1 and the resin subsequently washed with DCM (3 x $5 \mathrm{~mL})$ and DMF ( 3 x $5 \mathrm{~mL})$. Fmoc-Ala-OH (5 eq.) was pre-activated for 2 minutes in DMF (final concentration $0.5 \mathrm{M}$ ) following the addition of HCTU (4.7 eq.), OxymaPure® (4.7 eq.) and DIPEA (12 eq.). The preactivated Fmoc-protected amino acid was transferred to the resin and the resulting mixture was agitated (bubbling $\mathrm{N}_{2}$ through the syringe) for 2 hours at room temperature. The resin was subsequently drained and another freshly-prepared batch of pre-activated Fmoc-Ala-OH was added. The resulting mixture was agitated for 3 hours, before the resin was drained and washed with DMF ( $3 \times 5 \mathrm{~mL})$, DCM (3 x $5 \mathrm{~mL}$ ), and DMF ( 5 x $5 \mathrm{~mL}$ ). All remaining, unreacted amine groups were capped by adding a solution of acetic anhydride:pyridine (3:2) to the resin. After agitating the mixture for 30 minutes, the resin was washed with DMF (4 x $5 \mathrm{~mL})$, DCM $(2 \times 5 \mathrm{~mL})$, DMF ( $3 \times 5 \mathrm{~mL})$, and $\operatorname{DCM}(5 \times 5 \mathrm{~mL})$. The resin was then dried under vacuum and stored at $-20^{\circ} \mathrm{C}$ until further use. A small sample $(10 \mathrm{mg})$ of the dried resin was removed to determine the loading efficiency. For this, the resin was first swollen for 30 minutes in $800 \mu \mathrm{L}$ of DMF, after which $200 \mu \mathrm{L}$ of piperidine was added. The mixture was vortexed to ensure good mixing and left in a tabletop shaker (room temperature, $300 \mathrm{rpm}$ ) for $15 \mathrm{~min}$. An aliquot of the mixture $(100 \mu \mathrm{L})$ was diluted to $10 \mathrm{~mL}$ with $20 \%$ piperidine in DMF and the concentration of the piperidine-fulvene adduct $\left(\lambda=301 \mathrm{~nm}, \varepsilon=7800 \mathrm{M} \mathrm{cm}^{-1}\right)$ was determined using a spectrophotometer. The loading of the resin was determined using the following formula 
$\mathrm{L}=\mathrm{A}_{301} /(78 \times \mathrm{M})$

with $\mathrm{L}$ being the resin loading, $\mathrm{A}_{301}$ the absorbance at $301 \mathrm{~nm}$, and $\mathrm{M}$ the weight of the sample. The loadings obtained ranged from $0.35-0.55 \mathrm{mmol} / \mathrm{g}$.

Iterative peptide synthesis: Peptides were typically synthesized on a $0.05-0.1 \mathrm{mmol}$ scale. After an initial washing step (3 x $5 \mathrm{~mL}$ DMF) peptides were assembled following a cycle of deprotection and coupling steps.

Deprotection: The resin was treated with $20 \%$ piperidine/DMF (6 mL, 1 × 2 min., $2 \times 8$ min.) and washed with DMF (3 x $6 \mathrm{~mL}), \mathrm{DCM}(2 \times 6 \mathrm{~mL})$, and DMF (3 × $6 \mathrm{~mL})$. An aliquot at the end of every deprotection was taken and the absorption at $301 \mathrm{~nm}$ measured on the NanoDrop ${ }^{\mathrm{TM}}$ to ensure complete deprotection. Following the deprotection of the N-terminal amino acid, the resin was washed with DMF $(2 \times 6 \mathrm{~mL})$ and DCM $(5 \times 6 \mathrm{~mL})$ and subsequently dried under vacuum

Coupling: Fmoc-protected amino acids (6 eq.) were pre-activated for 2 minutes in DMF (final concentration $0.5 \mathrm{M}$ ) following the addition of $\mathrm{HCTU}$ (5.8 eq.), OxymaPure ${ }^{\circledR}$ (5.8 eq.) and DIPEA (13 eq.). Preactivated Fmoc-amino acids were transferred to the resin and the resulting mixture was agitated (bubbling $\mathrm{N}_{2}$ through the syringe) for 1 hour at room temperature. Subsequently, the resin was drained and washed with DMF (5 x 6 mL).

Cleavage and peptide isolation: A cleavage cocktail containing TFA/TIS/EDT/water $(90: 4: 4: 2 \mathrm{v} / \mathrm{v} / \mathrm{v} / \mathrm{v}, 10 \mathrm{~mL})$ was added to the dried resin and incubated at room temperature for 2 hours. Subsequently, the resulting mixture was filtered, the resin washed with TFA $(2 \times 3 \mathrm{~mL})$ and the resulting filtrate concentrated to $\sim 0.5 \mathrm{~mL}$ by blowing a constant stream of $\mathrm{N}_{2}$ over the solution. Peptides were then precipitated by the addition of ice-cold diethyl-ether $(20 \mathrm{~mL})$ and subsequently pelleted by centrifugation $(3,000 \mathrm{rpm})$. The supernatant was carefully removed 
by decantation and the precipitate washed twice with ice-cold ether $(20 \mathrm{~mL})$ to remove organic impurities. Residual ether was removed by blowing a constant stream of $\mathrm{N}_{2}$ over the sample and the residue subsequently dissolved in $0.1 \%$ TFA (aq.) and freeze-dried. Peptides obtained from this procedure were used without any further purification in cyclization experiments. AVSSGGCWA-NH 2 (74.8 mg, 79\% yield), KVSSGGCWA- $\mathrm{NH}_{2}(53.1 \mathrm{mg}, 90 \%$ yield), Ac$K V S S G G C W A-\mathrm{NH}_{2}\left(34 \mathrm{mg}, 56 \%\right.$ yield), AVSSGGSGCWA-NH $\mathrm{H}_{2}(85.2 \mathrm{mg}, 78 \%$ yield), and AVNEKHYCWA-NH $\mathrm{H}_{2} \quad(131 \mathrm{mg}, 98 \%$ yield $)$ were obtained as white solids following lyophilization.

\section{CHEMICAL SYNTHESIS}

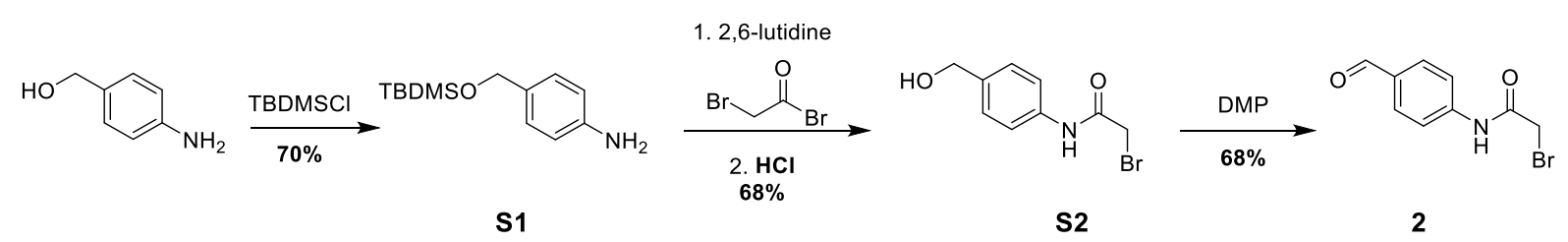

S1: Compound S1 was synthesized as described previously. ${ }^{[1]}$ 4-aminobenzyl alcohol (500 mg, $4.06 \mathrm{mmol})$, TBDMS-Cl (612 mg, $4.06 \mathrm{mmol})$, and imidazole (553 mg, $8.12 \mathrm{mmol})$, were dissolved in anhydrous DMF $(7 \mathrm{~mL})$. The resulting solution was stirred for $1 \mathrm{~h}$ at room temperature. After that, water $(20 \mathrm{~mL})$ was added and the product extracted with EtOAc $(3 \mathrm{x}$ $50 \mathrm{~mL}$ ). The combined organic layers were washed with saturated $\mathrm{NaHCO}_{3}$ (aq.), water, and brine, and dried over $\mathrm{MgSO}_{4}$. The solvent was evaporated and the residue purified by silica column chromatography (10-30\% EtOAc in heptane) to yield $672 \mathrm{mg}$ (70\%) of TBDMS ether S1 as a pale-yellow oil. ${ }^{1} \mathrm{H}-\mathrm{NMR}(400 \mathrm{MHz}$, Chloroform-d) $\delta 7.11(\mathrm{~d}, \mathrm{~J}=8.3 \mathrm{~Hz}, 2 \mathrm{H}), 6.66$ (d, $\mathrm{J}=8.4 \mathrm{~Hz}, 2 \mathrm{H}), 4.62(\mathrm{~s}, 2 \mathrm{H}), 3.61(\mathrm{~s}, 2 \mathrm{H}), 0.93(\mathrm{~s}, 9 \mathrm{H}), 0.08(\mathrm{~s}, 6 \mathrm{H}) .{ }^{13} \mathrm{C}-\mathrm{NMR}(101 \mathrm{MHz}$, cdc13) $\delta 145.46,131.70,127.83,115.12,65.14,26.14,18.58,-5.00$. HRMS (ESI-TOF) m/z 238.1625 (238.1622 calc. for $\mathrm{C}_{13} \mathrm{H}_{24} \mathrm{NOSi},[\mathrm{M}+\mathrm{H}]^{+}$). 
S2: 2,6-lutidine $(0.788 \mathrm{~mL}, 6.8 \mathrm{mmol})$ and bromoacetyl bromide $(0.329 \mathrm{~mL}, 3.80 \mathrm{mmol})$ were added under $\mathrm{N}_{2}$ atmosphere at $4{ }^{\circ} \mathrm{C}$ to a solution of TBDMS protected 4-aminobenzyl alcohol (S1, $600 \mathrm{mg}, 2.52 \mathrm{mmol})$ in dry DCM (6 mL). After stirring for one hour, the reaction was quenched by addition of $1 \mathrm{M} \mathrm{HCl}$ (aq., $10 \mathrm{~mL}$ ). DCM was removed under vacuum and $\mathrm{MeOH}$ (20 $\mathrm{mL}$ ) added. The reaction was then stirred for $30 \mathrm{~min}$ to allow for the removal of the TBDMS protecting group. Excess methanol was removed and the resulting water phase extracted three times with EtOAc $(50 \mathrm{~mL})$. The organic phases were combined, washed with water and brine and subsequently dried over $\mathrm{MgSO}_{4}$. EtOAc was removed in vacuo and the off-white product repeatedly washed with ice-cold DCM (3x $3 \mathrm{~mL})$, to yield $200 \mathrm{mg} \mathrm{S2}(68 \%)$ as a white solid. ${ }^{1} \mathrm{H}-\mathrm{NMR}(400 \mathrm{MHz}$, Methanol-d4) $\delta 7.55(\mathrm{~d}, \mathrm{~J}=8.1 \mathrm{~Hz}, 2 \mathrm{H}), 7.33(\mathrm{~d}, \mathrm{~J}=8.0 \mathrm{~Hz}, 2 \mathrm{H}), 4.57$ (s, 2H), 3.97 (s, 2H). ${ }^{13} \mathrm{C}-\mathrm{NMR}(101 \mathrm{MHz}, \mathrm{cd} 3 \mathrm{od}) \delta 167.64,139.13,138.54,128.64,121.13,64.76$, 29.68. HRMS (ESI-TOF) $\mathrm{m} / \mathrm{z} 242.9895$ and 244.9868 (242.9889 and 244.9869 calc. for $\left.\mathrm{C}_{9} \mathrm{H}_{11} \mathrm{BrNO}_{2},[\mathrm{M}+\mathrm{H}]^{+}\right)$and $225.9866\left(225.9867\right.$ calc. for $\left.\mathrm{C}_{9} \mathrm{H}_{9} \mathrm{BrNO}^{+}\left[\mathrm{M}-\mathrm{H}_{2} \mathrm{O}\right]^{+}\right)$.

2: The bi-functional scaffold $\mathbf{S 3}$ was obtained by adapting a procedure of Toshima et al. ${ }^{[22]}$ Dess-Martin periodinane $(383 \mathrm{mg}, 0.901 \mathrm{mmol})$ was added under $\mathrm{N}_{2}$ atmosphere at room temperature to a solution of the acetamide compound $\mathbf{S 2}(200 \mathrm{mg}, 0.819 \mathrm{mmol})$ in acetonitrile (5 mL). The resulting solution was stirred for one hour or until TLC indicated full conversion. Subsequently, any precipitates formed during the reaction were filtered and washed with acetonitrile. The filtrate was then concentrated and purified by silica column chromatography (20-50\% EtOAc in heptane), to give $128 \mathrm{mg} 2$ (68\% yield) as white/translucent crystals. ${ }^{1} \mathrm{H}-$ NMR (400 MHz, DMSO-d6) $\delta 10.79$ (s, 1H), 9.90 (s, 1H), 7.89 (d, J = 8.6 Hz, 2H), 7.80 (d, J $=8.6 \mathrm{~Hz}, 2 \mathrm{H}), 4.13(\mathrm{~s}, 2 \mathrm{H}) .{ }^{13} \mathrm{C}-\mathrm{NMR}(101 \mathrm{MHz}, \mathrm{dmso}) \delta 191.64,165.55,144.04,131.77$, $130.89,118.97,30.27$

HRMS (ESI-TOF) m/z 239.9670 and 241.9650 (239.9655 and 241.9634 calc. for $\mathrm{C}_{9} \mathrm{H}_{9} \mathrm{BrNO}_{2}$, $\left.[\mathrm{M}-\mathrm{H}]^{-}\right)$. 


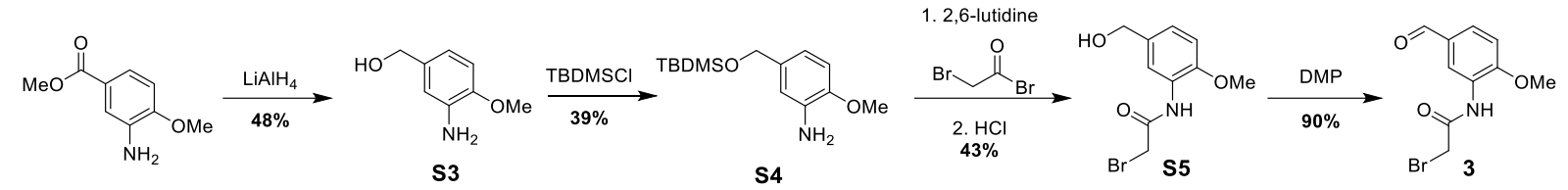

S3: To obtain amino alcohol S3 a previously-described procedure by Toshima et al. was adapted. ${ }^{[22]} \mathrm{LiAlH}_{4}(314 \mathrm{mg}, 8.3 \mathrm{mmol})$ was added to a solution of methyl 3-amino-4methoxybenzoate $(1.0 \mathrm{~g}, 5.5 \mathrm{mmol})$ in dry THF $(20.0 \mathrm{~mL})$ under $\mathrm{N}_{2}$ atmosphere in an ice bath. The reaction mixture was stirred for 1 hour at room temperature or until TLC analysis (30\% EtOAc in heptane) confirmed full conversion. The reaction was quenched by the slow addition of $\mathrm{MeOH}(15 \mathrm{~mL})$ and subsequently EtOAc $(15 \mathrm{~mL})$ was added. After the solution was stirred for $15 \mathrm{~min}$ at room temperature, the solvents were removed in vacuo. Water $(25 \mathrm{~mL})$ was added and the product was extracted with EtOAc $(60 \mathrm{~mL} \times 3)$. The extracts were washed with brine (60 mL), dried over anhydrous $\mathrm{Na}_{2} \mathrm{SO}_{4}$, filtered, and concentrated in vacuo. The residue was purified by silica column chromatography (45-100\% EtOAc in heptane) to yield S3 (444 mg, $2.90 \mathrm{mmol}, 48 \%)$ as a white solid. ${ }^{1} \mathrm{H}-\mathrm{NMR}(400 \mathrm{MHz}$, Chloroform-d) $\delta 6.86-6.60(\mathrm{~m}, 3 \mathrm{H})$, 4.53 (s, 2H), 3.85 (s, 3H).; ${ }^{13} \mathrm{C}-\mathrm{NMR}$ (101 MHz, Chloroform-d) $\delta$ 147.11, 135.71, 133.95, 117.41, 114.20, 110.43, 65.47, 55.72.; HRMS (ESI-TOF) m/z 154.0860 (154.0863 calc. for $\left.\mathrm{C}_{8} \mathrm{H}_{12} \mathrm{NO}_{2},[\mathrm{M}+\mathrm{H}]^{+}\right)$.

S4: TBDMS-protected compound $\mathbf{S 4}$ was prepared as described for $\mathbf{S 1}$ and was isolated as offwhite solid (275 mg, 39\%) by silica column chromatography (45\%-100\% EtOAc in heptane). ${ }^{1} \mathrm{H}-\mathrm{NMR}(400 \mathrm{MHz}, \mathrm{DMSO}-\mathrm{d} 6): \delta 6.72(\mathrm{~d}, \mathrm{~J}=8.1 \mathrm{~Hz}, 1 \mathrm{H}), 6.59(\mathrm{~d}, \mathrm{~J}=2.1 \mathrm{~Hz}, 1 \mathrm{H}), 6.45$ (dd, $\mathrm{J}=8.1,2.1 \mathrm{~Hz}, 1 \mathrm{H}), 4.66(\mathrm{~s}, 2 \mathrm{H}), 4.50(\mathrm{~s}, 2 \mathrm{H}), 3.73(\mathrm{~s}, 3 \mathrm{H}), 0.88(\mathrm{~s}, 9 \mathrm{H}), 0.05(\mathrm{~s}, 6 \mathrm{H}) ;{ }^{13} \mathrm{C}-$ NMR (101 MHz, DMSO-d6): $\delta$ 145.48, 137.32, 133.42, 114.18, 112.24, 110.09, 64.59, 55.29, 26.23, 18.03, -5.74; HRMS (ESI-TOF) m/z 268.1727 (268.1727 calc. for $\mathrm{C}_{14} \mathrm{H}_{26} \mathrm{NO}_{2} \mathrm{Si}$, $\left.[\mathrm{M}+\mathrm{H}]^{+}\right)$. 
S5: Following the procedure as described for compound S2, acetamide S5 was obtained as brown solid (85 mg, 43\%). ${ }^{1} \mathrm{H}-\mathrm{NMR}(400 \mathrm{MHz}$, Methanol-d4) $\delta 8.05(\mathrm{~d}, \mathrm{~J}=2.2 \mathrm{~Hz}, 1 \mathrm{H}), 7.14$ $(\mathrm{dd}, \mathrm{J}=8.4,2.1 \mathrm{~Hz}, 1 \mathrm{H}), 7.00(\mathrm{~d}, \mathrm{~J}=8.4 \mathrm{~Hz}, 1 \mathrm{H}), 4.53(\mathrm{~s}, 2 \mathrm{H}), 4.10(\mathrm{~s}, 2 \mathrm{H}), 3.89(\mathrm{~s}, 3 \mathrm{H}) . ;{ }^{13} \mathrm{C}-$ NMR (101 MHz, Methanol-d4) $\delta 167.36,150.60,134.97,127.66,125.34,121.83,111.69$, 64.97, 56.48, 29.80.; HRMS (ESI-TOF) m/z 274.0070 (274.0073 calc. for $\mathrm{C}_{10} \mathrm{H}_{13} \mathrm{BrNO}_{3}$, $\left.[\mathrm{M}+\mathrm{H}]^{+}\right)$and $255.9967\left(255.9973\right.$ calc. for $\left.\mathrm{C}_{10} \mathrm{H}_{11} \mathrm{BrNO}_{2},\left[\mathrm{M}-\mathrm{H}_{2} \mathrm{O}\right]^{+}\right)$.

3: Following the procedure for $\mathbf{2}$, the bifunctional scaffold $\mathbf{3}$ was obtained as a white solid (54 mg, 0.20 mmol, 90\%). ${ }^{1} \mathrm{H}-\mathrm{NMR}$ (400 MHz, DMSO-d6) $\delta 9.86$ (s, 1H), 9.81 (s, 1H), 8.54 (s, 1H), $7.73(\mathrm{~d}, \mathrm{~J}=10.2 \mathrm{~Hz}, 1 \mathrm{H}), 7.29(\mathrm{~d}, \mathrm{~J}=8.5 \mathrm{~Hz}, 1 \mathrm{H}), 4.23(\mathrm{~s}, 2 \mathrm{H}), 3.97$ (s, 3H).; ${ }^{13} \mathrm{C}-\mathrm{NMR}$ $(151 \mathrm{MHz}, \mathrm{DMSO}-\mathrm{d} 6) \delta 191.51,165.45,154.30,129.25,128.54,127.42,120.96,111.39$, 56.41, 30.15; HRMS (ESI-TOF) m/z 270.9837 and 272.9816 (270.9839 and 272.9818 calc. For $\left.\mathrm{C}_{10} \mathrm{H}_{10} \mathrm{BrNO}_{3},[\mathrm{M}+\mathrm{H}]^{+}\right)$.

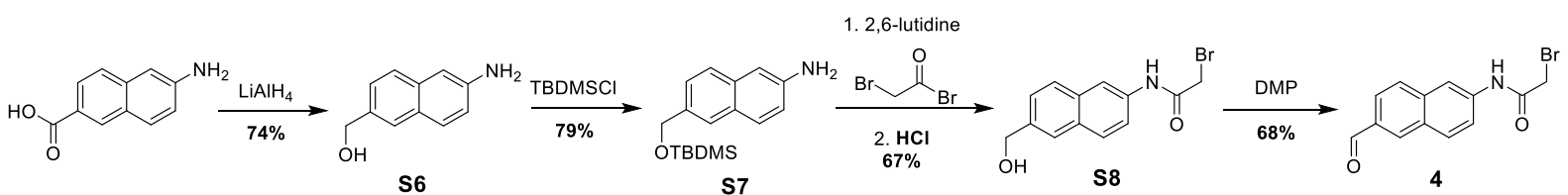

S6: (6-Aminonaphthyl)methanol (S6) was obtained following a procedure described by Sergeyev et al. ${ }^{[23]} \mathrm{LiAlH}_{4}(1 \mathrm{M}, 12.82 \mathrm{mmol})$ was added dropwise at $0{ }^{\circ} \mathrm{C}$ to a solution of (6aminonaphthyl)carboxylic acid (800 mg, $4.27 \mathrm{mmol})$ in dry THF (20 mL). After the addition was completed, the mixture was stirred for $1 \mathrm{~h}$ at room temperature and then heated to reflux for an additional $2 \mathrm{~h}$. The mixture was allowed to reach room temperature and quenched by the dropwise addition of water $(2 \mathrm{~mL})$. The inorganic precipitate was filtered and the filtrate dried over $\mathrm{MgSO}_{4}$ and concentrated to give $\mathbf{S 6}(549 \mathrm{mg}, 74 \%)$ as a slightly brownish solid. ${ }^{1} \mathrm{H}-\mathrm{NMR}$ (400 MHz, dmso) $\delta 7.57-7.49(\mathrm{~m}, 2 \mathrm{H}), 7.44(\mathrm{~d}, \mathrm{~J}=8.4 \mathrm{~Hz}, 1 \mathrm{H}), 7.23(\mathrm{dd}, \mathrm{J}=8.4,1.7 \mathrm{~Hz}$ 1H), $6.90(\mathrm{dd}, \mathrm{J}=8.7,2.2 \mathrm{~Hz}, 1 \mathrm{H}), 6.78(\mathrm{~d}, \mathrm{~J}=2.2 \mathrm{~Hz}, 1 \mathrm{H}), 5.26(\mathrm{~s}, 2 \mathrm{H}), 5.08(\mathrm{t}, \mathrm{J}=5.7 \mathrm{~Hz}$ 1H), $4.52(\mathrm{~d}, \mathrm{~J}=5.6 \mathrm{~Hz}, 2 \mathrm{H}) .{ }^{13} \mathrm{C}-\mathrm{NMR}(101 \mathrm{MHz}, \mathrm{dmso}) \delta 146.33,134.89,133.60,128.34$, 
126.10, 125.56, 124.95, 122.84, 118.84, 105.96, 63.27. HRMS (ESI-TOF) m/z 174.0916 (174.0913 calc. for $\left.\mathrm{C}_{11} \mathrm{H}_{12} \mathrm{NO},[\mathrm{M}+\mathrm{H}]^{+}\right)$.

S7: TBDMS-protected compound $\mathbf{S 7}$ was prepared as described for $\mathbf{S 1}$ and obtained as offwhite solid (619 mg, 79\%). ${ }^{1} \mathrm{H}-\mathrm{NMR}(400 \mathrm{MHz}, \mathrm{dmso}) \delta 7.58-7.49$ (m, 2H), 7.46 (d, J = 8.5 $\mathrm{Hz}, 1 \mathrm{H}), 7.22(\mathrm{dd}, \mathrm{J}=8.4,1.7 \mathrm{~Hz}, 1 \mathrm{H}), 6.91(\mathrm{dd}, \mathrm{J}=8.7,2.2 \mathrm{~Hz}, 1 \mathrm{H}), 6.79(\mathrm{~d}, \mathrm{~J}=2.2 \mathrm{~Hz}, 1 \mathrm{H})$, $5.30(\mathrm{~s}, 2 \mathrm{H}), 4.73(\mathrm{~s}, 2 \mathrm{H}), 0.90(\mathrm{~s}, 9 \mathrm{H}), 0.08(\mathrm{~s}, 6 \mathrm{H}) .{ }^{13} \mathrm{C}-\mathrm{NMR}(101 \mathrm{MHz}, \mathrm{dmso}) \delta$ 146.51, $134.24,133.43,128.39,125.98,125.10,124.58,118.48,105.89,64.76,25.86,18.06,-5.15$. HRMS (ESI-TOF) m/z $288.1782\left(288.1778\right.$ calc. for $\left.\mathrm{C}_{17} \mathrm{H}_{26} \mathrm{NOSi},[\mathrm{M}+\mathrm{H}]^{+}\right)$.

S8: Following the procedure as described for compound $\mathbf{S 2}$, acetamide $\mathbf{S 8}$ was obtained as a yellow solid $200 \mathrm{mg}(67 \%)$. ${ }^{1} \mathrm{H}-\mathrm{NMR}(400 \mathrm{MHz}, \mathrm{dmso}) \delta 10.55(\mathrm{~s}, 1 \mathrm{H}), 8.26(\mathrm{~d}, \mathrm{~J}=2.1 \mathrm{~Hz}$, 1H), $7.86(\mathrm{~d}, \mathrm{~J}=8.8 \mathrm{~Hz}, 1 \mathrm{H}), 7.80(\mathrm{~d}, \mathrm{~J}=8.5 \mathrm{~Hz}, 1 \mathrm{H}), 7.76(\mathrm{~s}, 1 \mathrm{H}), 7.55(\mathrm{dd}, \mathrm{J}=8.8,2.1 \mathrm{~Hz}$, 1H), 7.44 (dd, J = 8.5, $1.7 \mathrm{~Hz}, 1 \mathrm{H}), 4.63$ (s, 2H), 4.09 (s, 2H). ${ }^{13} \mathrm{C}-\mathrm{NMR}$ (101 MHz, dmso) $\delta$ $164.96,139.19,135.78,132.38,129.88,128.37,127.23,125.92,124.18,119.77,115.49,62.95$, 30.45. HRMS (ESI-TOF) m/z 293.0048 and 295.0028 (293.0046 and 295.0026 calc. for $\left.\mathrm{C}_{13} \mathrm{H}_{12} \mathrm{BrNO}_{2},[\mathrm{M}+\mathrm{H}]^{+}\right)$and $276.0022\left(276.0024\right.$ calc. for $\left.\mathrm{C}_{13} \mathrm{H}_{11} \mathrm{BrNO},\left[\mathrm{M}-\mathrm{H}_{2} \mathrm{O}\right]^{+}\right)$.

4: Following the procedure for $\mathbf{2}$, the bifunctional scaffold $\mathbf{4}$ was obtained as an off-white solid $102 \mathrm{mg}(68 \%) .{ }^{1} \mathrm{H}-\mathrm{NMR}(400 \mathrm{MHz}, \mathrm{dmso}) \delta 10.79(\mathrm{~s}, 1 \mathrm{H}), 10.11(\mathrm{~s}, 1 \mathrm{H}), 8.51(\mathrm{~d}, \mathrm{~J}=1.6 \mathrm{~Hz}$, $1 \mathrm{H}), 8.41(\mathrm{~d}, \mathrm{~J}=2.1 \mathrm{~Hz}, 1 \mathrm{H}), 8.14(\mathrm{~d}, \mathrm{~J}=8.8 \mathrm{~Hz}, 1 \mathrm{H}), 8.00(\mathrm{~d}, \mathrm{~J}=8.6 \mathrm{~Hz}, 1 \mathrm{H}), 7.86(\mathrm{dd}, \mathrm{J}=$ 8.6, $1.6 \mathrm{~Hz}, 1 \mathrm{H}), 7.71(\mathrm{dd}, \mathrm{J}=8.8,2.1 \mathrm{~Hz}, 1 \mathrm{H}), 4.13(\mathrm{~s}, 2 \mathrm{H}) .{ }^{13} \mathrm{C}-\mathrm{NMR}(101 \mathrm{MHz}, \mathrm{dmso}) \delta$ $192.67,165.45,139.13,136.64,134.15,132.89,130.65,129.02,128.52,123.05,120.69$, 115.26, 30.35. HRMS (ESI-TOF) m/z 289.98242 and 291.9803 (289.9811 and 291.9791 calc. For $\left.\mathrm{C}_{13} \mathrm{H}_{19} \mathrm{BrNO}_{2},[\mathrm{M}-\mathrm{H}]^{-}\right)$. 


\section{PEPTIDE CYCLIZATION REACTIONS}

Cyclization reactions of model peptides (pep1-5) with cyclization moieties 1-4: Crude lyophilized $\left(25 \mu \mathrm{L}\right.$ of a $20 \mathrm{mM}$ stock solution in $0.1 \%$ TFA), $\mathrm{ddH}_{2} \mathrm{O}(187.5 \mu \mathrm{L})$, acetonitrile $(100 \mu \mathrm{L})$, TCEP $\left(37.5 \mu \mathrm{L}\right.$ of a $4 \mathrm{mM}$ stock in $\left.\mathrm{ddH}_{2} \mathrm{O}\right)$, and cyclization units $(100 \mu \mathrm{L}$ of $15 \mathrm{mM}$ stock solutions in acetonitrile) were added sequentially to MOPS buffer (500 $\mu \mathrm{L}, 200 \mathrm{mM}$, pH 6.5). The resulting solutions were incubated at $30{ }^{\circ} \mathrm{C}$ for 3 hours or until UPLC-MS analysis indicated $>95 \%$ conversion to the modified peptide. At this stage $\mathrm{NaBH}_{3} \mathrm{CN}$ ( $20 \mu \mathrm{L}$ of a 200 $\mathrm{mM}$ stock solution in $\mathrm{ddH}_{2} \mathrm{O}$ ) was added and the reaction was incubated overnight at $4{ }^{\circ} \mathrm{C}$. The next morning two more portions of $\mathrm{NaBH}_{3} \mathrm{CN}$ were added in three-hour intervals (final concentration $10 \mathrm{mM}$ in the reactions) and the resulting reaction mixtures were analyzed by UPLC-MS.

Cyclization for 1D and 2D-NMR spectroscopy studies: Crude, lyophilized peptide (1 eq., 3$4 \mathrm{mg}, \sim 3 \mathrm{mmol}$ ), 100-110 $\mu \mathrm{L}$ acetonitrile, cyclization unit 1 (1.05 eq., $~ 3.15 \mathrm{mmol}, 90-100 \mu \mathrm{L}$ of a $31 \mathrm{mM}$ stock solution in acetonitrile $)$, and $\mathrm{ddH}_{2} \mathrm{O}(600 \mu \mathrm{L})$ were added to phosphate buffer (100 $\mu \mathrm{L}, 200 \mathrm{mM}, \mathrm{pH} 6.5)$. The resulting solutions were incubated at $30^{\circ} \mathrm{C}$ for 3 hours or until $>95 \%$ of the starting peptide was modified as indicated by UPLC-MS analysis. At this stage $\mathrm{NaBH}_{3} \mathrm{CN}\left(40 \mu \mathrm{L}\right.$ of a $50 \mathrm{mM}$ stock solution in $\mathrm{H}_{2} \mathrm{O}$ ) was added and the reaction was incubated overnight at $4{ }^{\circ} \mathrm{C}$. The next day, three more portions of $\mathrm{NaBH}_{3} \mathrm{CN}(3 \times 20 \mu \mathrm{L}$ of a $50 \mathrm{mM}$ stock solution in $\mathrm{H}_{2} \mathrm{O}$ ) were added in four-hour intervals (final concentration $5 \mathrm{mM}$ ). After UPLCMS analysis indicated full conversion to the reduced product, the reactions mixtures were lyophilized. The resulting, crude cyclic peptides were then dissolved in $550 \mu \mathrm{L}$ of an NMR solvent consisting of: $50 \mu \mathrm{L} \mathrm{D} \mathrm{D}_{2} \mathrm{O}, 100-200 \mu \mathrm{L} 0.1 \%$ TFA in $\mathrm{H}_{2} \mathrm{O}(\mathrm{pH} \sim 4-5)$, and 300-400 $\mu \mathrm{L}$ $\mathrm{H}_{2} \mathrm{O}$. To obtain an NMR sample of the modified peptides, reaction mixtures were lyophilized following the initial modification step. 


\section{MOLECULAR BIOLOGY}

The gene encoding for the fusion protein pep-TEV-D1D2 was obtained via the following steps: (1) construction of AGSSGGC-D1D2 and its insertion into pET21b(+); (2) insertion of the TEV cleave site to obtain AGSSGGC-TEV-D1D2; and (3) site-directed mutagenesis of AGSSGCTEV-D1D2 into AㅌSSGGC-TEV-D1D2 (= pep-TEV-D1D2).

Construction of pET21b(+)-D1D2 and pET21b(+)-AGSSGGC-D1D2: The gene encoding for the disulfide-free D1D2 domains as well as AGSSGGC-D1D2 were amplified from fdg3p0ss2 ${ }^{[16]}$ using the primers NdeI_D1D2_fw or NdeI_pep_D1D2_fw and XhoI_D1D2_rv, which also installed appropriate restriction enzyme sites for restriction digest (see the primer list at the end of this section) using the following PCR protocol: (1) initial denaturation $98{ }^{\circ} \mathrm{C}$ for $1 \mathrm{~min}$, (2) 30 cycles of denaturation at $98{ }^{\circ} \mathrm{C}$ for $10 \mathrm{~s}$, annealing at $54{ }^{\circ} \mathrm{C}$ for $30 \mathrm{~s}$ and extension at $72{ }^{\circ} \mathrm{C}$ for $30 \mathrm{~s}$; (3) a final extension at $72{ }^{\circ} \mathrm{C}$ for $10 \mathrm{~min}$. Successful amplification as well as the size of the PCR products was verified by agarose gel (1\%). The remaining template was removed by DpnI digestion at $37{ }^{\circ} \mathrm{C}$ for 16 hours. Following PCR purification, the resulting constructs were cloned into pET21b(+) following standard restriction enzyme cloning procedures (NdeI and XhoI). Ligation mixtures were transformed into chemicallycompeted E. coli NEB10 $\beta$ cells and successful transformants identified after overnight incubation on selective LB agar plates containing ampicillin. Single colonies were picked and the identity of the inserts confirmed by Sanger sequencing to give the plasmids pET21b(+)D1D2 and pET21b(+)-AGSSGGC-D1D2.

Construction of pET21b(+)-AGSSGGC-TEV-D1D2: The TEV cleavage site in the AGGSSGGC-D1D2 gene was installed by overlap extension PCR combining fragments obtained following PCR amplification of pET21b(+)-AGSSGGC-D1D2 with the primer pairs TEV_fw1/rv1 and TEV_fw2/ rv2. The two fragments were joined using TEV_fw1 and 
TEV_rv2 using the following touchdown PCR protocol: (1) initial denaturation $98^{\circ} \mathrm{C}$ for 2 min, (2) 16 cycles of denaturation at $98{ }^{\circ} \mathrm{C}$ for $10 \mathrm{~s}$, annealing at $64-56{ }^{\circ} \mathrm{C}$ for $30 \mathrm{~s}$ and extension at $72{ }^{\circ} \mathrm{C}$ for $30 \mathrm{~s}$; (3) 14 cycles of denaturation at $98{ }^{\circ} \mathrm{C}$ for $10 \mathrm{~s}$, annealing at $56{ }^{\circ} \mathrm{C}$ for $30 \mathrm{~s}$ and extension at $72{ }^{\circ} \mathrm{C}$ for $30 \mathrm{~s}$; (4) final extension at $72{ }^{\circ} \mathrm{C}$ for $5 \mathrm{~min}$. The resulting construct AGSSGGC-TEV-D1D2 was inserted into pET21b(+) and transformed into chemicallycompetent E.coli NEB10 $\beta$ cells as described before. The identity of the insert in the resulting pET21b(+)AGSSGGC-TEV-D1D2 was confirmed by sequencing.

Construction of pET21b(+)pep-TEV-D1D2: pET21b(+)-pept-TEV-D1D2 was obtained by QuikChange site-directed mutagenesis of pET21b(+)-AGSSGGC-TEV-D1D2 using SDM_Val_fw and SDM_Val_rv as primers. Following DpnI digestion and PCR cleanup the resulting PCR product was transformed into chemically-competent E.coli NEB10 $\beta$ cells and the identity of the insert confirmed by sequencing. Lastly, the resulting plasmid pET21b(+)pepTEV-D1D2 as well as the previously obtained pET21b(+)-D1D2 were transformed into chemically-competent E. coli BL21 DE3 cells.

Protein production and purification: Flasks containing $500 \mathrm{~mL} \mathrm{LB}$-medium with $100 \mu \mathrm{g} / \mathrm{mL}$ ampicillin were inoculated with $2.5 \mathrm{~mL}$ of a densely grown overnight culture of $E$. coli BL21(DE3) cells harboring plasmids pET21b(+)-D1D2 or pET21b(+)-pep-TEV-D1D2. Cells were incubated at $37{ }^{\circ} \mathrm{C}$ while shaking $(135 \mathrm{rpm})$ until an $\mathrm{OD}_{600}$ of $0.4-0.6$ was reached (approx. $4 \mathrm{~h}$ ). At this stage, gene expression was induced by addition of isopropyl $\beta$-D-1thiogalactopyranoside (IPTG, final concentration $1 \mathrm{mM}$ ) and incubation was continued for 16 hours at $30{ }^{\circ} \mathrm{C}$. Cells were harvested by centrifugation (6,000 rpm, JLA10.500 Beckman, 20 $\min , 4{ }^{\circ} \mathrm{C}$ ) and the supernatant discarded. The cell pellet was resuspended in $20 \mathrm{~mL}$ washing buffer $\left(50 \mathrm{mM} \mathrm{NaH}_{2} \mathrm{PO}_{4}, 150 \mathrm{mM} \mathrm{NaCl}, \mathrm{pH} 7.5\right)$ containing $1 \mathrm{mg} / \mathrm{mL}$ egg white lysozyme and a tablet of protease inhibitor cocktail (cOmplete ${ }^{\mathrm{TM}}$ Mini, Roche). Cell suspension was subsequently lysed by sonication (70\% (200 W) for $10 \mathrm{~min}, 15 \mathrm{sec}$ on, $10 \mathrm{sec}$ off). The lysed 
cells were centrifuged to remove cell debris $\left(12,000 \mathrm{rpm}, \mathrm{JA}-17.5,60 \mathrm{~min} .,{ }^{\circ} \mathrm{C}\right)$, the cleared lysate was purified by Ni-NTA chromatography (GE Healthcare) according to the supplier's specifications. His-tagged D1D2 variants were eluted with elution buffer $\left(50 \mathrm{mM} \mathrm{NaH} \mathrm{PO}_{4}\right.$, $150 \mathrm{mM} \mathrm{NaCl}, 250 \mathrm{mM}$ imidazole, $\mathrm{pH}$ 7.5). Protein containing fractions, as judged by SDSPAGE, were pooled and concentrated using filtration tubes with a cut-off of $15 \mathrm{kDa}(4,000 \mathrm{rpm}$, JLA-17.5, $\left.60 \mathrm{~min}, 4{ }^{\circ} \mathrm{C}\right)$. Phosphate buffer $\left(50 \mathrm{mM} \mathrm{NaH}{ }_{2} \mathrm{PO}_{4}, 150 \mathrm{mM} \mathrm{NaCl}, \mathrm{pH} 7.5\right)$ was repeatedly added to remove the imidazole. Protein aliquots $(\sim 1 \mathrm{~mL})$ were stored at $4{ }^{\circ} \mathrm{C}$ or -20 ${ }^{\circ} \mathrm{C}$ until further use. Concentrations were determined by measuring the absorbance at $280 \mathrm{~nm}$ on a NanoDrop 2000 (Thermoscientific) spectrophotometer with calculated extinction coefficients $\left(49,850 \mathrm{M}^{-1} \mathrm{~cm}^{-1}\right.$ for D1D2 and TEV-D1D2). Yields were $137 \mathrm{mg}$ for D1D2 and 97 mg pep-TEV-D1D2, per liter culture.

Construction of fd_pep -D1D2: The gene encoding for pep-TEV-D1D2 was amplified from the corresponding pET21b(+) plasmid using the primers SfiI_fd_fw and SfiI_fd_rv according to the following protocol: 1) initial denaturation $98^{\circ} \mathrm{C}$ for $2 \mathrm{~min}$, (2) 40 cycles of denaturation at $98{ }^{\circ} \mathrm{C}$ for $20 \mathrm{~s}$, annealing at $58{ }^{\circ} \mathrm{C}$ for $45 \mathrm{~s}$ and extension at $72{ }^{\circ} \mathrm{C}$ for $1 \mathrm{~min}$; (3) a final extension at $72{ }^{\circ} \mathrm{C}$ for $7 \mathrm{~min}$. Following DpnI digestion at $37{ }^{\circ} \mathrm{C}$ for 16 hours and PCR purification, the resulting constructs were digested with SfiI for $5 \mathrm{~h}$ at $50{ }^{\circ} \mathrm{C}$. In parallel, the recipient fd phage vector fd0D1D2 was linearized by incubation with EcoRI for $2 \mathrm{~h}$ at $37{ }^{\circ} \mathrm{C}$ and subsequently digested by SfiI at $50{ }^{\circ} \mathrm{C}$ for $3 \mathrm{~h}$. The resulting products from both SfiI digestions were ligated using $\mathrm{T} 4$ ligase at $37{ }^{\circ} \mathrm{C}$ for $1 \mathrm{~h}$ and the crude ligation mixture transformed into chemically-competed TG1 E. coli cells. Successful transformants were identified after overnight incubation on selective 2xYT agar plates containing chloramphenicol. Single colonies were picked and the identity of the inserts confirmed by Sanger sequencing to give fd_pep-D1D2. 


\section{PROTEIN CYCLIZATION AND TEV CLEAVAGE}

Cyclization of pep-TEV-D1D2 with cyclization moieties 1-4: TCEP (50 $\mu \mathrm{L}$ from a $10 \mathrm{mM}$ stock in $\left.\mathrm{ddH}_{2} \mathrm{O}\right)$, and $\mathrm{ddH}_{2} \mathrm{O}(80 \mu \mathrm{L})$ were added to $870 \mu \mathrm{L}$ of a solution containing D1D2 or pep-TEV-D1D2 (92 $\mu \mathrm{M}$ stock solution in $50 \mathrm{mM} \mathrm{NaH}_{2} \mathrm{PO}_{4}, 150 \mathrm{mM} \mathrm{NaCl}, \mathrm{pH}$ 7.5). The resulting reaction was incubated at $30{ }^{\circ} \mathrm{C}$ for $30 \mathrm{~min}$ to allow for reduction of any disulfides formed during phage production. The sample was split evenly into $2 \times 500 \mu \mathrm{L}$ fractions, which were eluted over a PD MiniTrap ${ }^{\text {TM }}$ column (GE Healthcare, 2.1 mL of Sephadex ${ }^{\mathrm{TM}}$ G-25 resin) with $1 \mathrm{~mL}$ MOPS buffer $(100 \mathrm{mM}, \mathrm{pH} 7)$. At this point an aliquot of the sample was removed for UPLC-MS analysis. Next, cyclization units 1-4 (50 $\mu \mathrm{L}$ from a $5 \mathrm{mM}$ stock solution in acetonitrile) were added to $500 \mu \mathrm{L}$ of a solution containing reduced protein samples. After 5 hours, UPLC-MS analysis confirmed complete modification for pep-TEV-D1D2, after which the modified proteins were eluted over a new PD MiniTrap ${ }^{\mathrm{TM}}$ column with $1 \mathrm{~mL}$ MES buffer (50 mM, pH 6). At this stage $\mathrm{NaBH}_{3} \mathrm{CN}\left(10 \mu \mathrm{L}\right.$ from a $100 \mathrm{mM}$ stock in $\mathrm{ddH}_{2} \mathrm{O}$ ) was added and the reaction was incubated overnight at $4{ }^{\circ} \mathrm{C}$. The next day, four more portions of $\mathrm{NaBH}_{3} \mathrm{CN}$ were added ( $4 \times 10 \mu \mathrm{L}$ from a $100 \mathrm{mM}$ stock in $\mathrm{ddH}_{2} \mathrm{O}$ ) in three-hour intervals (final concentration $5 \mathrm{mM}$ ) and the reactions were incubated for an additional 16 hours at $4{ }^{\circ} \mathrm{C}$. The reaction mixtures were then subjected to UPLC-MS analysis to determine the conversion to cyclized pep-TEV-D1D2.

TEV cleavage of AVSSGGC-TEV-D1D2 after cyclization: TEV protease $(1 \mu \mathrm{L}$, SigmaAldrich) was added to $50 \mu \mathrm{L}$ of cyclized protein sample obtained from the procedure described above. The reaction mixture was incubated at $30{ }^{\circ} \mathrm{C}$ for $3 \mathrm{~h}$ before an additional $1 \mu \mathrm{L}$ aliquot of TEV protease was added. The resulting reaction mixtures were incubated at $4{ }^{\circ} \mathrm{C}$ overnight and subjected to UPLC-MS analysis the next day. 


\section{PHAGE PRODUCTION AND INFECTIVITY STUDIES}

Production fd_pep-D1D2 phages: Flasks containing $500 \mathrm{~mL}$ 2xYT-medium with $30 \mu \mathrm{g} / \mathrm{mL}$ chloramphenicol were inoculated with $2.5 \mathrm{~mL}$ of a densely grown overnight culture of E.coli TG1 cells harboring the fd_pep-D1D2 plasmid and incubated overnight at $30{ }^{\circ} \mathrm{C}$ at $135 \mathrm{rpm}$. The cultures were subsequently centrifuged $\left(6,000 \mathrm{rpm}\right.$, JLA10.500 Beckman, $\left.20 \mathrm{~min}, 4{ }^{\circ} \mathrm{C}\right)$ and the phage-containing supernatant was decanted to new centrifuges bottles. From the phage solution, a $50 \mu 1$ 'supernatant' aliquot was taken and stored at $4{ }^{\circ} \mathrm{C}$ for infectivity studies (see below). A solution of ice-cold PEG-NaCl solution (125 mL, 20\% PEG-6000 (w/v), 2.5 M NaCl) was added to the supernatant and the resulting mixture incubated on ice for $30 \mathrm{~min}$. Phages that precipitated during this time were pelleted by centrifugation $(9.500 \mathrm{rpm}$, JLA10.500 Beckman, 45 min, $4{ }^{\circ} \mathrm{C}$ ). The supernatant was carefully decanted and the centrifuge bottle placed upside down on a filter paper for 2 min to remove all residual liquid. The phage pellet was then resuspended in $20 \mathrm{~mL}$ degassed reaction buffer $(20 \mathrm{mM}$ HEPES containing $5 \mathrm{mM}$ EDTA at $\mathrm{pH}$ 8.0) and the mixture was transferred into a $50 \mathrm{~mL}$ Greiner tube. Remaining cell/phage debris was removed by centrifugation (4000 rpm, Eppendorf A-4-62, $15 \mathrm{~min}, 4{ }^{\circ} \mathrm{C}$ ) and the supernatant carefully transferred into a new $50 \mathrm{~mL}$ Greiner tube. At this point a $50 \mu 1$ 'PEG precipitation' aliquot was taken and stored at $4{ }^{\circ} \mathrm{C}$. TCEP (final concentration $1 \mathrm{mM}$ ) was added to the PEG-purified phages and the resulting reaction mixture was incubated at $42{ }^{\circ} \mathrm{C}$ for $1 \mathrm{~h}$. Samples were concentrated to $1 \mathrm{~mL}$ using Amicon® Ultra-15 (cut off of $100 \mathrm{kDa}$ ) centrifugation tubes. Next, reduced phages were washed three times with $12 \mathrm{ml}$ ice-cold reaction buffer (20 mM HEPES, $5 \mathrm{mM}$ EDTA, $\mathrm{pH}$ 8). Phages prone to accumulate on the filter during this procedure were resuspended by pipetting samples up and down repeatedly. After the final wash, samples were concentrated to $1 \mathrm{~mL}$, transferred to a $15 \mathrm{~mL}$ tube and the volume adjusted with reaction buffer to $9 \mathrm{~mL}$. At this point, a 'TCEP reduction' aliquot was taken and stored at $4{ }^{\circ} \mathrm{C}$. 
Cyclization on phages: Cyclization units $1-4(1 \mathrm{~mL}$ of $0.5-5 \mathrm{mM}$ stock solutions in acetonitrile) were added to phage samples obtained after TCEP reduction and the resulting reaction mixtures were incubated at $30^{\circ} \mathrm{C}$ for $1 \mathrm{~h}$. The samples were subsequently concentrated to $1 \mathrm{~mL}$ and washed three times with reduction buffer (50 mM MES, $\mathrm{pH}$ 6) as described above. Following the final wash, samples were concentrated to $1 \mathrm{~mL}$, transferred to a $15 \mathrm{~mL}$ tube and the volume adjusted with reduction buffer to $9 \mathrm{~mL}$. At this point, a 50 'Cys-modification' aliquot was taken and stored at $4{ }^{\circ} \mathrm{C} . \mathrm{NaBH}_{3} \mathrm{CN}(2 \times 200 \mu \mathrm{L}$ from $25 \mathrm{mM}$ stock) was added to the phage samples and the reaction was incubated overnight at $4{ }^{\circ} \mathrm{C}$. The next morning, three more batches of $\mathrm{NaBH}_{3} \mathrm{CN}$ ( 3 × $200 \mu \mathrm{L}$ from $25 \mathrm{mM}$ stock) were added in $2 \mathrm{~h}$ time intervals to reach a final concentration of $2.5 \mathrm{mM}$ in the reaction mixture. Samples were subsequently concentrated to $1 \mathrm{~mL}$ and washed three times with reduction buffer (50 mM MES, pH 6) as described above. Following the final wash, samples were concentrated to $1 \mathrm{~mL}$, transferred to a $15 \mathrm{~mL}$ tube and the volume adjusted with reduction buffer to $10 \mathrm{~mL}$. At this point a $50 \mu \mathrm{l}$ ' $\mathrm{NaBH}_{3} \mathrm{CN}$ reduction' aliquot was taken and stored at $4{ }^{\circ} \mathrm{C}$.

Infectivity studies: Stored $50 \mu \mathrm{L}$ aliquots of the 'supernatant', 'PEG-purifaction', 'TCEP reduction', 'cyc-modification', and ' $\mathrm{NaBH}_{3} \mathrm{CN}$ reduction' were used to determine the phage infectivity after every handling step. For each sample, seven 10 -fold dilutions in 2 XYT were prepared. Aliquots $(20 \mu \mathrm{L})$ of samples corresponding to $10^{-5}, 10^{-6}$, and $10^{-7}$ dilutions were added to $180 \mu \mathrm{L}$ of E.coli TG1 cells growing in the mid-log phase (OD $600 \sim 0.4)$. Phages in the samples were allowed to infect cells at $37^{\circ} \mathrm{C}$ at $135 \mathrm{rpm}$. for $90 \mathrm{~min}$. An aliquot $(50 \mu \mathrm{L})$ of each dilution was then plated onto $2 \mathrm{xYT} / \mathrm{chloramphenicol} \mathrm{agar} \mathrm{plates} \mathrm{and} \mathrm{incubated} \mathrm{overnight} \mathrm{at} 37{ }^{\circ} \mathrm{C}$. The next day, colonies on the plates were counted and the number of infectious phages was calculated by adjusting for the corresponding dilution factors. 
PRIMER LIST

\begin{tabular}{|c|c|}
\hline Name & Sequence 5' $\rightarrow$ 3' \\
v & GTGGTGCTCGAGAGCATTGACAGGAGGTTGAGG \\
\hline $\begin{array}{c}\text { Xhol_D1D2r } \\
\text { w }\end{array}$ & GGAATTCCATATGGCTGAAACTGTTGAAAGT \\
\hline $\begin{array}{c}\text { NdeI_pept- } \\
\text { D1D2_fw }\end{array}$ & GGAATTCCATATGGCTGGTAGCAGTGGCGGTTGCGCTGAAACTGTTGAAA \\
\hline TEV_fw1 & ATAG \\
\hline TEV_fw2 & GAAAACCTGTACTTCCAGTCGGCTGAAACTGTTGAAAGTAGTTTAGC \\
\hline TEV_rv1 & CGACTGGAAGTACAGGTTTTCGCAACCGCCACTGCTACC \\
\hline TEV_rv2 & GTGGTGCTCGAGAGCATTGAC \\
\hline SDM_Val_fw & GGAGATATACATATGGCTGTTAGCAGTGGCGGTTGCG \\
\hline SDM_Val_rv & CGCAACCGCCACTGCTAACAGCCATATGTATATCTCC \\
\hline SfiI_fd_fw & TATGCGGCCCAGCCGGCCATGGCAGCTGTTAGCAGTGGCGGTTGCG \\
\hline SfiI_fd_rv & GAAGCCATGGCCCCCGAGGCCCCGGACGGAGCATTGACAGG \\
\hline
\end{tabular}




\section{REFERENCES}

[1] a) E. M. Driggers, S. P. Hale, J. Lee, N. K. Terrett, Nat. Rev. Drug. Discov. 2008, 7, 608624; b) E. Valeur, S. M. Gueret, H. Adihou, R. Gopalakrishnan, M. Lemurell, et al., Angew. Chem. Int. Ed. 2017, 56, 10294-10323; c) A. Zorzi, K. Deyle, C. Heinis, Curr. Opin. Chem. Biol. 2017, 38, 24-29; d) C. Morrison, Nat. Rev. Drug. Discov. 2018, 17, 531-533; e) A. A. Vinogradov, Y. Yin, H. Suga, J. Am. Chem. Soc. 2019, 141, $4167-$ 4181.

[2] a) D. P. Fairlie, J. D. Tyndall, R. C. Reid, A. K. Wong, G. Abbenante, et al., J. Med. Chem. 2000, 43, 1271-1281; b) D. Wang, W. Liao, P. S. Arora, Angew. Chem. Int. Ed. 2005, 44, 6525-6529; c) E. A. Villar, D. Beglov, S. Chennamadhavuni, J. A. Porco, Jr., D. Kozakov, et al., Nat. Chem. Biol. 2014, 10, 723-731; d) A. K. Malde, T. A. Hill, A. Iyer, D. P. Fairlie, Chem. Rev. 2019, 119, 9861-9914.

[3] a) J. L. Lau, M. K. Dunn, Bioorg. Med. Chem. 2018, 26, 2700-2707; b) T. Passioura, T. Katoh, Y. Goto, H. Suga, Annu. Rev. Biochem. 2014, 83, 727-752.

[4] a) C. I. Cheigh, Y. R. Pyun, Biotechnol. Lett. 2005, 27, 1641-1648; b) Y. Yu, L. Duan, Q. Zhang, R. Liao, Y. Ding, et al., ACS Chem. Biol. 2009, 4, 855-864; c) H. Luo, S. Y. Hong, R. M. Sgambelluri, E. Angelos, X. Li, et al., Chem. Biol. 2014, 21, 1610-1617.

[5] a) C. J. White, A. K. Yudin, Nat. Chem. 2011, 3, 509-524; b) A. K. Yudin, Chem. Sci. 2015, 6, 30-49; c) L. R. Malins, J. N. deGruyter, K. J. Robbins, P. M. Scola, M. D. Eastgate, et al., J. Am. Chem. Soc. 2017, 139, 5233-5241; d) R. Derda, M. R. Jafari, Protein Pept. Lett. 2018, 25, 1051-1075.

[6] a) J. M. Smith, J. R. Frost, R. Fasan, J. Org. Chem. 2013, 78, 3525-3531; b) R. Obexer, L. J. Walport, H. Suga, Curr. Opin. Chem. Biol. 2017, 38, 52-61; c) C. Sohrabi, A. Foster, A. Tavassoli, Nat. Rev, Chem. 2020, 4, 90-101.

[7] a) G. P. Smith, V. A. Petrenko, Chem. Rev. 1997, 97, 391-410; b) S. S. Sidhu, H. B. Lowman, B. C. Cunningham, J. A. Wells, Methods Enzymol. 2000, 328, 333-363.

[8] a) K. T. O'Neil, R. H. Hoess, S. A. Jackson, N. S. Ramachandran, S. A. Mousa, et al., Proteins 1992, 14, 509-515; b) M. A. McLafferty, R. B. Kent, R. C. Ladner, W. Markland, Gene 1993, 128, 29-36; c) K. A. Noren, C. J. Noren, Methods 2001, 23, 169-178; d) S. Chen, I. Rentero Rebollo, S. A. Buth, J. Morales-Sanfrutos, J. Touati, et al., J. Am. Chem. Soc. 2013, 135, 6562-6569.

[9] a) X. S. Wang, P. C. Chen, J. T. Hampton, J. M. Tharp, C. A. Reed, et al., Angew. Chem. Int. Ed. 2019, 58, 15904-15909; b) A. E. Owens, J. A. Iannuzzelli, Y. Gu, R. Fasan, ACS Cent. Sci. 2020, 6, 368-381.

[10] C. Heinis, G. Winter, Curr. Opin. Chem. Biol. 2015, 26, 89-98.

[11] a) S. Kalhor-Monfared, M. R. Jafari, J. T. Patterson, P. I. Kitov, J. J. Dwyer, et al., Chem. Sci. 2016, 7, 3785-3790; b) M. R. Jafari, L. Deng, P. I. Kitov, S. Ng, W. L. Matochko, et al., ACS Chem. Biol. 2014, 9, 443-450; c) C. Heinis, T. Rutherford, S. Freund, G. Winter, Nat. Chem. Biol. 2009, 5, 502-507; d) I. Rentero Rebollo, C. Heinis, Methods 2013, 60, 
46-54; e) S. Chen, J. Morales-Sanfrutos, A. Angelini, B. Cutting, C. Heinis, ChemBioChem 2012, 13, 1032-1038.

[12] a) A. Ekanayake, L. Sobze, J. Youk, N. J. Bennett, R. Mukherjee, et al., 2020; b) C. Ernst, J. Sindlinger, D. Schwarzer, P. Koch, F. M. Boeckler, ACS Omega 2018, 3, 12361-12368; c) S. S. Kale, C. Villequey, X. D. Kong, A. Zorzi, K. Deyle, et al., Nat. Chem. 2018, 10, 715-723.

[13] a) J. N. deGruyter, L. R. Malins, P. S. Baran, Biochemistry 2017, 56, 3863-3873; b) O. Boutureira, G. J. Bernardes, Chem. Rev. 2015, 115, 2174-2195.

[14] a) J. M. Smith, N. C. Hill, P. J. Krasniak, R. Fasan, Org. Biomol. Chem. 2014, 12, $1135-$ 1142; b) J. M. Smith, F. Vitali, S. A. Archer, R. Fasan, Angew. Chem. Int. Ed. 2011, 50, 5075-5080; c) M. Satyanarayana, F. Vitali, J. R. Frost, R. Fasan, Chem. Commun. 2012, $48,1461-1463$.

[15] a) J. M. Gilmore, R. A. Scheck, A. P. Esser-Kahn, N. S. Joshi, M. B. Francis, Angew. Chem. Int. Ed. 2006, 45, 5307-5311; b) C. B. Rosen, M. B. Francis, Nat. Chem. Biol. 2017, 13, 697-705; c) A. Onoda, N. Inoue, E. Sumiyoshi, T. Hayashi, ChemBioChem 2020, 21, 1274-1278.

[16] I. Kather, C. A. Bippes, F. X. Schmid, J. Mol. Biol. 2005, 354, 666-678.

[17] a) M. Khalaj-Kondori, M. Sadeghizadeh, M. Behmanesh, I. Saggio, P. Monaci, J Gene Med 2011, 13, 622-631; b) T. J. Molenaar, I. Michon, S. A. de Haas, T. J. van Berkel, J. Kuiper, et al., Virology 2002, 293, 182-191.

[18] V. Adebomi, R. D. Cohen, R. Wills, H. A. H. Chavers, G. E. Martin, et al., Angew. Chem. Int. Ed. 2019, 58, 19073-19080.

[19] a) C. Grant, F. Rahman, R. Piekarz, C. Peer, R. Frye, et al., Expert Rev Anticancer Ther 2010, 10, 997-1008; b) W. Bauer, U. Briner, W. Doepfner, R. Haller, R. Huguenin, et al., Life Sci 1982, 31, 1133-1140; c) T. Kaushik, M. M. Yaqoob, Biologics 2013, 7, 243-246.

[20] Z. Zhang, A. G. Marshall, J Am Soc Mass Spectrom 1998, 9, 225-233.

[21] H. Xie, D. Ng, S. N. Savinov, B. Dey, P. D. Kwong, et al., J. Med. Chem. 2007, 50, 48984908.

[22] D. Kuwahara, T. Hasumi, H. Kaneko, M. Unno, D. Takahashi, et al., Chem. Commun. 2014, 50, 15601-15604.

[23] S. Sergeyev, M. Schar, P. Seiler, O. Lukoyanova, L. Echegoyen, et al., Chem. Eur. J. 2005, 11, 2284-2294. 


\section{ACKNOWLEDGEMENTS}

CM and TRO are thankful to Dr. Johan Kemmink and Pieter van der Meulen for their help in performing and analyzing the NMR experiments and would like to thank Rudy Rubini for his guidance in molecular biology operations. The authors are grateful to Prof. Christian Heinis, for providing phage vectors fdg3p0ss21 and fd0D1D2 with permission from Prof. Franz.X. Schmid. CM and TRO acknowledge Anthony Kromodimedjo and Catalina Bigalke for the synthesis of cyclization unit 3 . 